\title{
Paweł Felis* Zróżnicowanie fiskalnych skutków Grzegorz Otczyk** gminnej polityki podatkowej w Polsce
}

\section{Diversity of fiscal consequences of municipal tax policy in Poland}

The article explores the subject of diversification of local tax policy and its fiscal consequences in Poland in 2007-2019. It focuses on various types of municipalities and tax governance tools they use (establishing tax rates, applying tax exemptions and non-statutory reliefs). The analysed taxes include immovable property taxes (property tax, agricultural tax) and movable property ones (tax on means of transport). Theoretical and empirical analyses confirmed the hypotheses. Polish municipalities utilize tax governance tools on a small scale and their taxation policies differ depending on the category of local tax and the type of municipality.

\begin{tabular}{|c|c|}
\hline DOI & https://doi.org/10.31268/StudiaBAS.2021.06 \\
\hline Słowa kluczowe & $\begin{array}{l}\text { samorząd terytorialny w Polsce, gminy, podatki lokalne w Polsce, } \\
\text { lokalna polityka podatkowa, władztwo podatkowe }\end{array}$ \\
\hline Keywords & $\begin{array}{l}\text { local government in Poland, municipalities, local taxes in Poland, local } \\
\text { tax policy, tax control }\end{array}$ \\
\hline 0 autorach & $\begin{array}{l}\text { * doktor hab. nauk ekonomicznych, profesor uczelni w Instytucie } \\
\text { Finansów, Szkoła Główna Handlowa w Warszawie • } \\
\square \text { pfelis@sgh.waw.pl • ORCID 0000-0002-2072-7245 } \\
\text { ** doktorant w Kolegium Zarządzania i Finansów Szkoły Głównej } \\
\text { Handlowej • } ₫ \text { grzegorz.otczyk@doktorant.sgh.waw.pl • } \\
\text { ORCID 0000-0002-2431-4309 }\end{array}$ \\
\hline
\end{tabular}

\section{Wstęp}

Gminy w Polsce są zasilane dochodami własnymi, których katalog i szczegółowy opis zawarto w ustawie o dochodach jednostek samorządu terytorialnego ${ }^{1}$. Składają się na nie przede wszystkim: podatki lokalne, udziały we wpływach z tytułu państwowych podatków dochodowych, dochody z majątku. Podatki lokalne to ważny element samorządności, dzięki nim władze gminne mają bowiem możliwość oddziaływania na rozwój źródeł tych dochodów i kształtowania ich wysokości. W literaturze podkreśla się, iż samodzielność dochodowa gmin - oprócz tego, że jest podstawowym atrybutem samorządności - stanowi niezbędny warunek harmonijnego i zrównoważonego rozwoju². Z podatkami lokalnymi wiąże się tzw. ograniczone władztwo podatkowe, zdeterminowane z jednej strony konstytucyjną zasadą uchwalania podatków przez parlament, z drugiej - przyznaniem gminom prawa ustalania wysokości podatków lokalnych w ustawowym zakresie. Można wyróżnić dwie grupy podatków zasilających samorządy gminne:

1 Ustawa z dnia 13 listopada 2003 r. o dochodach jednostek samorządu terytorialnego (Dz.U. 2021, poz. 38, ze zm.).

2 K. Brzozowska, M. Kogut-Jaworska, Władztwo podatkowe wocenie samodzielności dochodowej gmin w Polsce, „Annales Universitatis Mariae Curie-Skłodowska. Sectio H. Oeconomia” 2016, t. 50, nr 1, s. 329, https://doi. org/10.17951/h.2016.50.1.327. 
- pierwszą (podatek od nieruchomości, podatek rolny, podatek leśny oraz podatek od środków transportowych), w której władztwo podatkowe przejawia się w możliwości oddziaływania na konstrukcję podatków przez obniżanie i różnicowanie stawek podatkowych, wprowadzanie własnych zwolnień przedmiotowych (w podatku rolnym także ulg podatkowych) oraz stosowanie indywidualnych obniżek;

- drugą (podatek od czynności cywilnoprawnych, podatek od spadków i darowizn oraz podatek dochodowy opłacany w formie karty podatkowej), w której władztwo podatkowe polega jedynie na udzielaniu indywidualnych zwolnień, ulg oraz rozkładaniu na raty płatności podatkowych. Przedmiotem badań podjętych w artykule jest pierwsza grupa podatków lokalnych, a celem - rozpoznanie zróżnicowania fiskalnych skutków decyzji z zakresu władztwa podatkowego z zastosowaniem takich kryteriów, jak rodzaj podatku lokalnego i jego wydajność fiskalna oraz rodzaj gmin (miasta na prawach powiatu, gminy miejskie, gminy miejsko-wiejskie oraz gminy wiejskie). Poddano także weryfikacji następujące hipotezy badawcze:

- Skala wykorzystania narzędzi lokalnej polityki podatkowej w Polsce pozostaje wciąż niewielka.

- Lokalna polityka podatkowa jest bardziej aktywna i wywołuje większe skutki fiskalne w jednostkach biedniejszych, mających mniejszą bazę podatkową.

Gminy w ramach lokalnej polityki podatkowej mają możliwość kształtowania stawek podatkowych (bezpośrednio w drodze uchwalania ich wysokości lub pośrednio, przez wykorzystanie tzw. stabilizatorów, tj. obniżenie ceny skupu żyta lub drewna) oraz stosowania ulg i zwolnień, a także narzędzi przewidzianych w Ordynacji podatkowej. Analizą objęto długi okres, tj. lata 2007-2019, z wykorzystaniem metod poznania empirycznego (obserwacji, porównania i pomiaru). Oparto się przede wszystkim na danych udostępnionych przez Ministerstwo Finansów.

\section{Lokalna polityka podatkowa w dotychczasowych badaniach}

W Polsce do głównych źródeł dochodów własnych gminy należą m.in. podatek od nieruchomości i podatek od środków transportowych. Ten pierwszy jest liczony od powierzchni nieruchomości, co w Europie stanowi rzadkie rozwiązanie. W toku analizy gminnej polityki podatkowej trudno więc nawiązywać do badań prowadzonych za granicą. Podatek od środków transportowych także nie występuje powszechnie w innych krajach.

W prowadzonych w Polsce w ostatnim czasie badaniach nad stosowaną polityką podatkową w zakresie podatków lokalnych poruszono m.in. następujące problemy:

- zróżnicowanie polityki podatkowej gmin w zakresie najważniejszych podatków lokalnych,

- intensywność i skuteczność wykorzystywanych narzędzi w ramach przyznanego gminom władztwa podatkowego,

- finansowe i pozafinansowe skutki polityki podatkowej.

Najważniejsze wnioski dotyczące lokalnej polityki podatkowej, do jakich doszli badacze zagadnienia, brzmią:

- polityka podatkowa nie tylko stanowi przejaw posiadanego przez organy gminy władztwa podatkowego i biernego realizowania uprawnień wynikających z delegacji ustawowych, 
lecz także jest realnym instrumentem stosowanym w celu realizacji funkcji fiskalnej i pozafiskalnej3;

- gminy nie prowadzą wystarczająco elastycznej polityki nakierowanej na utrzymanie dochodów na stałym poziomie, a kiedy obniżają stawki podatkowe oraz stosują własne ulgi i zwolnienia, kierują się celami pozafiskalnymi;

- skuteczność obniżania stawek podatku od nieruchomości w celu przyciągnięcia nowych inwestorów na lokalny rynek jest niewielka (słaba zależność między stawkami podatku od budynków związanych z prowadzeniem działalności gospodarczej a wielkościami opisującymi ilościowo funkcjonowanie podmiotów gospodarczych na terenie gmin ${ }^{5}$;

- konkurencja podatkowa jest koncepcją przydatną do wyjaśnienia różnic w polityce realizowanej przez poszczególne gminy";

- polityka podatkowa jest skorelowana z wysokością dochodów podatkowych, ale ten związek nie jest stały;

- badania naukowe potwierdzają zależność między typem gminy a zakresem jej polityki podatkowej ${ }^{8}$;

- spośród wszystkich narzędzi lokalnej polityki podatkowej najczęściej wykorzystywane są obniżki stawek podatkowych w podatku od nieruchomości9.

3 B.Z. Filipiak, Polityka podatkowa gmin czy realizacja władztwa podatkowego?, „Finanse, Rynki Finansowe, Ubezpieczenia" 2015, nr 76, t. 1, http://dx.doi.org/10.18276/frfu.2015.76/1-19; M. Poniatowicz, D. Wyszkowska, Stymulowanie rozwoju lokalnej przedsiębiorczości a konkurencja podatkowa gmin, „Zeszyty Naukowe Wyższej Szkoły Bankowej w Poznaniu" 2014, t. 52, nr 1; T. Skica, A. Kiebała, T. Wołowiec, Stymulowanie lokalnej konkurencyjności gmin na przykładzie podatku od środków transportowych, „Studia Regionalne i Lokalne” 2011, $\operatorname{nr} 2(44)$.

4 J. Śmiechowicz, Stabilność dochodów gmin w kontekście ich władztwa podatkowego i fakultatywności opłat Iokalnych , „Studia Ekonomiczne. Zeszyty Naukowe Uniwersytetu Ekonomicznego w Katowicach” 2016, nr 294.

5 M. Korolewska, Polityka podatkowa gmin i miast na prawach powiatu w zakresie podatku od nieruchomości a wspieranie przedsiębiorczości przez samorząd terytorialny , "Studia BAS” 2014, nr 1(37) [Rozwój przedsiębiorczości oraz sektora małych i średnich przedsiębiorstw, red. G. Gołębiowski].

6 P. Swianiewicz, J. Łukomska, Lokalna konkurencja podatkowa w Polsce, „Studia Regionalne i Lokalne” 2016, nr 2(64), https://doi.org/10.7366/1509499526401.

7 P. Felis, H. Rosłaniec, Wykorzystanie podatku od nieruchomości w lokalnej polityce podatkowej miast Unii Metropolii Polskich, "Gospodarka Narodowa” 2017, t. 288, nr 2, https://doi.org/10.33119/GN/100735; P. Felis, H. Rosłaniec, Zróżnicowanie fiskalnych skutków polityki podatkowej gmin w Polsce w zakresie podatku od środków transportowych, ,Studia Regionalne i Lokalne” 2017, nr 2(68), http://dx.doi.org/10.7366/150949956805.

8 J. Dziuba, Zróżnicowanie fiskalnych skutków polityki podatkowej jednostek samorzqdu terytorialnego, „Annales Universitatis Mariae Curie-Skłodowska. Sectio H. Oeconomia" 2016, t. 50, nr 1, http://dx.doi. org/10.17951/h.2016.50.1.351; J. Dziuba, Polityka podatkowa gmin wiejskich w Polsce w latach 2006-2017, „Zeszyty Naukowe Szkoły Głównej Gospodarstwa Wiejskiego. Ekonomika i Organizacja Gospodarki Żywnościowej" 2019, nr 125, http://dx.doi.org/10.22630/EIOGZ.2019.125.3; A. Kobiałka, Polityka podatkowa gmin w kontekście samodzielności finansowej, „Prace Naukowe Uniwersytetu Ekonomicznego we Wrocławiu” 2017, nr 488, http://dx.doi.org/10.15611/pn.2017.488.06.

9 K. Brzozowska, M. Kogut-Jaworska, op. cit; Z. Dolewka, Tax Control of the Commune and its Consequences, „Prace Naukowe Uniwersytetu Ekonomicznego we Wrocławiu” 2017, nr 476, https://doi.org/10.15611/ pn.2017.476.12; J. Olejniczak, D. Bednarska-Olejniczak, J. Mači, L. Svobodová, Real Property Tax in Polish Communes of the Polish-Czech Border Region, „Hradec Economic Days”, International Scientific Conference, 
Nie można również pomijać koncepcji tax expenditures w podatkach lokalnych, ponieważ wsparcie określonych celów społeczno-gospodarczych (w wyniku zastosowania odpowiednich preferencji podatkowych) wiąże się ze zmniejszeniem dochodów jednostek samorządu terytorialnego ${ }^{10}$.

\section{Teoretyczne i praktyczne aspekty władztwa podatkowego gmin w Polsce}

Jeżeli opowiedzieć się za podejściem, że samorząd gminny to podmiot publicznoprawny, który nie powinien się ograniczać wyłącznie do sfery użyteczności publicznej, ale musi także oddziaływać na działalność podmiotów funkcjonujących na jego terenie, trzeba stwierdzić, że powinno być dla niego charakterystyczne rzeczywiste partnerstwo jednostek gminnych w procesie stanowienia polityki fiskalnej.

Lokalną politykę podatkową definiujemy zatem jako świadome działania podejmowane przez samorząd lokalny zmierzające do osiągnięcia założonych celów, z wykorzystaniem odpowiednio dobranych metod, które wynikają z przyjętych norm prawnofinansowych. Zarówno realizacja podstawowych celów lokalnej polityki podatkowej (zaspokojenie popytu samorządowej władzy publicznej na pieniądz umożliwiające realizowanie funkcji lokalnych władz publicznych), jak i wykorzystanie jej poszczególnych narzędzi nie należą jednak do łatwych zadań. Konieczne są zatem ${ }^{11}$ :

- właściwie skonstruowany i rozwinięty system podatków lokalnych, którego logika powinna wynikać ze strategicznego celu realizowanego przez gminy;

- skuteczny aparat podatkowy, składający się z jednostek wymierzających i egzekwujących zobowiązania podatkowe oraz jednostek kontroli podatkowej;

- sprawny proces legislacyjny nie tylko zapewniający stabilność polityki podatkowej, lecz także reagujący bez opóźnień w zmieniających się warunkach społeczno-gospodarczych;

- zasilanie gmin środkami z budżetu państwa jako wyrównywanie dysproporcji w terytorialnym rozkładzie źródeł dochodów.

Lokalna polityka podatkowa jest determinowana wieloma czynnikami ${ }^{12}$ :

- zewnętrznymi (prawnymi i pozaprawnymi),

- wewnętrznymi (potencjałem gminy, kreatywnością władz, cechami społecznymi mieszkańców).

Hradec, 2-3 April 2020, https://doi.org/10.36689/uhk/hed/2020-01-032; R. Przygodzka, Władztwo podatkowe a stabilność finansowa gmin, „Nierówności Społeczne a Wzrost Gospodarczy” 2014, nr 4(40), http://polona. pl/item/43529479 [dostęp: 10 maja 2021 r.].

10 Por. m.in.: R. Dziemianowicz, R. Budlewska, Czy tax expenditures stosowane w podatkach państwowych maja wpływ na dochody JST? Przyczynek do dyskusji, „Prace Naukowe Uniwersytetu Ekonomicznego we Wrocławiu” 2015, nr 404 [Finanse samorzadu terytorialnego, red. L. Patrzałek, W. Kociemska]; A. Wyszkowski, Koncepcja tax expenditures w systemie podatkowym , "Gospodarka Narodowa” 2010, t. 242, nr 9, https://doi.org/10.33119/ GN/101165.

11 P. Felis, Podatki od nieruchomości a polityka podatkowa gmin w Polsce, Oficyna Wydawnicza SGH, Warszawa 2015, s. 80.

12 Ibidem, s. 86 in. 
Czynniki te należy traktować jako wartości zmienne, a ich wpływ na politykę podatkową poszczególnych gmin jest zróżnicowany. Powody stosowania określonej polityki podatkowej mogą być różne ${ }^{13}$, m.in. związane z celami fiskalnymi (dbałość o ściągalność podatków, chęć równoważenia budżetu bieżącego i majątkowego). Może także chodzić o stymulowanie lokalnego rozwoju gospodarczego (próba przyciągnięcia bazy podatkowej przez konkurencję podatkową) czy utrzymanie lub zwiększenie kapitału politycznego (spełnienie oczekiwań wyborców co do wysokości podatków). Inną kwestią jest skuteczność osiągania stawianych przed polityką podatkową celów w obecnym kształcie systemu podatków lokalnych.

Na władztwo podatkowe składają się m.in. uprawnienia do: stanowienia podatków, kształtowania (modelowania) obciążeń podatkowych, poboru podatków, przeciwdziałania przestępczości podatkowej oraz dysponowania wpływami z podatków ${ }^{14}$. Dla rozpatrywanego tematu istotne jest kształtowanie przez jednostki gminne - w ramach umocowania ustawowego - elementów konstrukcyjnych wpływających na wysokość zobowiązania podatkowego podatnika, np. przez obniżanie lub różnicowanie stawek podatkowych oraz rozszerzanie ustawowego katalogu zwolnień bądź ulg podatkowych. To, że gminy są uprawnione do czerpania dochodów z podatków, na których konstrukcję mogą oddziaływać, ma ogromną wagę dla ich samodzielności dochodowej, a w konsekwencji - stabilności finansowej ${ }^{15}$. Należy jednak podkreślić, że liczne źródła podatków i opłat lokalnych mają na ogół znaczenie marginalne z finansowego punktu widzenia.

Zakres władztwa podatkowego w poszczególnych dochodach przyznany przez ustawodawcę organom samorządu lokalnego ${ }^{16}$ jest zróżnicowany (tabela 1 ).

Rady gmin, w ramach przyznanego im władztwa podatkowego, mają prawo do samodzielnego kształtowania stawek podatku od nieruchomości - przez ich obniżanie lub utrzymywanie na ustawowym poziomie. Wskazanie w uchwale - która jest aktem prawa miejscowego - wysokości stawek podatkowych sprawia, że określone stawki zaczynają obowiązywać na terenie danej wspólnoty lokalnej. Na zakres władztwa podatkowego rady gminy składa się również upoważnienie do różnicowania wysokości stawek podatkowych wewnątrz poszczególnych grup przedmiotów opodatkowania. Takie decyzje mogą być podejmowane z uwzględnieniem następujących kryteriów: lokalizacji nieruchomości, rodzaju prowadzonej działalności, rodzaju zabudowy nieruchomości, przeznaczenia i sposobu wykorzystywania nieruchomości, stanu technicznego i wieku budynków.

Uprawnienia rady gminy w przypadku stawek podatku od środków transportowych sprowadzają się do ich określenia i różnicowania ich wysokości. Określając stawki dla poszczegól-

13 Szerzej na ten temat: J. Łukomska, P. Swianiewicz, Polityka podatkowa władz lokalnych w Polsce, Municipium, Warszawa 2015, s. 109 i n., https://doi.org/10.13140/RG.2.1.1928.0089.

14 J. Kulicki, Władztwo podatkowe państwa i samorzqdu terytorialnego w zakresie podatków dochodowych - model scentralizowany czy zdecentralizowany?, "Studia BAS” 2018, nr 2(54) [Wybrane zagadnienia reformy opodatkowania dochodów osób fizycznych i prawnych w Polsce, red. J. Kulicki], s. 93-94, https://doi.org/10.31268/ StudiaBAS.2018.05.

15 J. Śmiechowicz, Znaczenie podatków lokalnych w kontekście stabilizacji fiskalnej JST na przykładzie gmin województwa lubelskiego [w:] Dochody podatkowe samorzadu terytorialnego i czynniki je kształtujące, red. J. Szołno-Koguc, J. Śmiechowicz, Wydawnictwo UMCS, Lublin 2019, s. 114.

16 Więcej na ten temat: P. Felis, E. Malinowska-Misiąg, G. Otczyk, H. Rosłaniec, Planowanie dochodów z podatków lokalnych w Polsce, Oficyna Wydawnicza SGH, Warszawa 2020. 
Tabela 1. Uprawnienia gmin w odniesieniu do poszczególnych rodzajów podatków lokalnych

\begin{tabular}{|c|c|c|c|}
\hline Wyszczególnienie & $\begin{array}{l}\text { Kształtowanie } \\
\text { stawek } \\
\text { w granicach } \\
\text { ustalonych } \\
\text { ustawowo }\end{array}$ & $\begin{array}{c}\text { Wprowadzanie } \\
\text { ulg }\end{array}$ & $\begin{array}{l}\text { Wprowadzanie } \\
\text { zwolnień }\end{array}$ \\
\hline Podatek od nieruchomości & TAK & NIE & $\begin{array}{l}\text { TAK (tylko } \\
\text { przedmiotowe) }\end{array}$ \\
\hline Podatek rolny & $\mathrm{TAK}^{*}$ & $\begin{array}{l}\text { TAK (tylko } \\
\text { przedmiotowe) }\end{array}$ & $\begin{array}{l}\text { TAK (tylko } \\
\text { przedmiotowe) }\end{array}$ \\
\hline Podatek leśny & $\mathrm{TAK}^{\star *}$ & NIE & $\begin{array}{l}\text { TAK (tylko } \\
\text { przedmiotowe) }\end{array}$ \\
\hline Podatek od środków transportowych & TAK & NIE & $\begin{array}{l}\text { TAK (tylko } \\
\text { przedmiotowe) }\end{array}$ \\
\hline $\begin{array}{l}\text { Podatek od działalności gospodarczej osób } \\
\text { fizycznych opłacany w formie karty podatkowej }\end{array}$ & NIE & NIE & NIE \\
\hline Podatek od spadków i darowizn & NIE & NIE & NIE \\
\hline Podatek od czynności cywilnoprawnych & NIE & NIE & NIE \\
\hline
\end{tabular}

* Z wykorzystaniem tzw. stabilizatora - odnoszącego się do stawki podatku rolnego, przez obniżenie ceny skupu żyta.

** Z wykorzystaniem tzw. stabilizatora - odnoszącego się do stawki podatku leśnego, przez obniżenie ceny skupu drewna.

Źródło: opracowanie własne na podstawie: ustawy z dnia 12 stycznia 1992 r. o podatkach i opłatach lokalnych (Dz.U. 2019, poz. 1170, ze zm.); ustawy z dnia 15 listopada 1984 r. o podatku rolnym (Dz.U. 2020, poz. 333); ustawy z dnia 30 października 2002 r. o podatku leśnym (Dz.U. 2019, poz. 888); ustawy z dnia 9 września 2000 r. o podatku od czynności cywilnoprawnych (Dz.U. 2020, poz. 815, ze zm.); ustawy z dnia 28 lipca 1983 r. o podatku od spadków i darowizn (Dz.U. 2019, poz. 1813, ze zm.); ustawy z dnia 20 listopada 1998 r. o zryczałtowanym podatku dochodowym od niektórych przychodów osiąganych przez osoby fizyczne (Dz.U. 2019, poz. 43, ze zm.).

nych rodzajów przedmiotów opodatkowania, rada gminy uwzględnia w szczególności: wpływ środka transportowego na środowisko naturalne, rok produkcji albo liczbę miejsc do siedzenia. Wskazane przez ustawodawcę kryteria różnicowania stawek należy jednak traktować jako przykładowe, gdyż rady gmin mogą przyjąć zupełnie inne. Uprawnienia gmin w tym względzie są jednak ograniczone, ponieważ nie mogą one: ingerować w ustawowe kategorie pojazdów opodatkowanych, przekraczać stawek maksymalnych ani stosować różnicowania stawek w przypadku środków transportowych, dla których przewidziano stawki minimalne.

Podatki rolny i leśny w zakresie uprawnień przysługujących radzie gminy są do siebie podobne - rada ma pośredni wpływ na wysokość stawek podatkowych. Inaczej niż w przypadku opisanych dotychczas podatków nie może jednak bezpośrednio ustalać (obniżać) stawek podatkowych. Wyrazem władztwa podatkowego gminy jest prawo do obniżenia średniej ceny skupu żyta (przyjmowanej do obliczenia podatku rolnego) i średniej ceny sprzedaży drewna (będącej podstawą ustalenia stawki podatku leśnego). 


\section{Badanie empiryczne}

\section{Znaczenie wybranych podatków lokalnych jako źródeł dochodów gmin}

Lokalna polityka podatkowa w znacznym stopniu zależy od dochodów podatkowych, które gmina uzyskuje każdego roku. Ustawodawca przewidział możliwość oddziaływania na wysokość części podatków i uzyskiwanych przez gminy dochodów. Dla podatników oznacza to zmianę ponoszonych przez nich kosztów podatkowych.

Na dochody własne gminy składa się wiele podatków, w tym te, do których kształtowania gminy mają uprawnienia. Należą do nich - jak już wspomniano - podatek od nieruchomości, podatek rolny, podatek leśny ${ }^{17}$ oraz podatek od środków transportowych.

Wykres 1. Udział sumy dochodów z podatków: od nieruchomości, rolnego, leśnego i od środków transportowych, w dochodach własnych gmin w latach 2007-2019 (w \%)

60

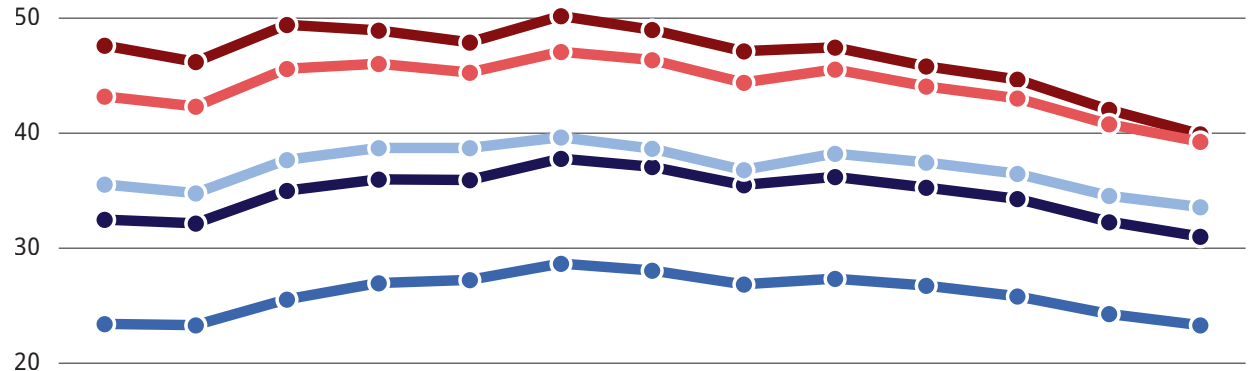

10

0

\begin{tabular}{|c|c|}
\hline 2007 & 20 \\
\hline
\end{tabular}

-00 gminy ogółem

-10 miasta na prawach powiatu

gminy miejskie

-0) gminy wiejskie

-Or gminy miejsko-wiejskie

Źródło: opracowanie własne na podstawie danych z aneksu 1.

Udział tych czterech podatków - utożsamianych z samodzielnością dochodową - w dochodach własnych gmin zmniejsza się na przestrzeni kilku ostatnich lat i w 2019 r. osiągnął nieco niższy poziom (31\%) niż w 2007 r. (32,5\%). Kwoty nominalne dochodów z tych podatków w kolejnych latach jednak rosną (aneks 1).

17 Podatek leśny, który jest podatkiem od majątku nieruchomego, nie był szczegółowo analizowany. 
Spośród czterech wyszczególnionych podatków największy udział w dochodach własnych gmin mają dochody z podatku od nieruchomości. Dochody z podatku rolnego i podatku od środków transportowych stanowią niewielki odsetek dochodów gmin (wykres 2). Jeśli chodzi o podatek leśny, to jego wysokość jest minimalna i ma on znaczenie marginalne.

Wykres 2. Udziały wybranych podatków w dochodach własnych gmin w latach 2007-2019 (w \%)

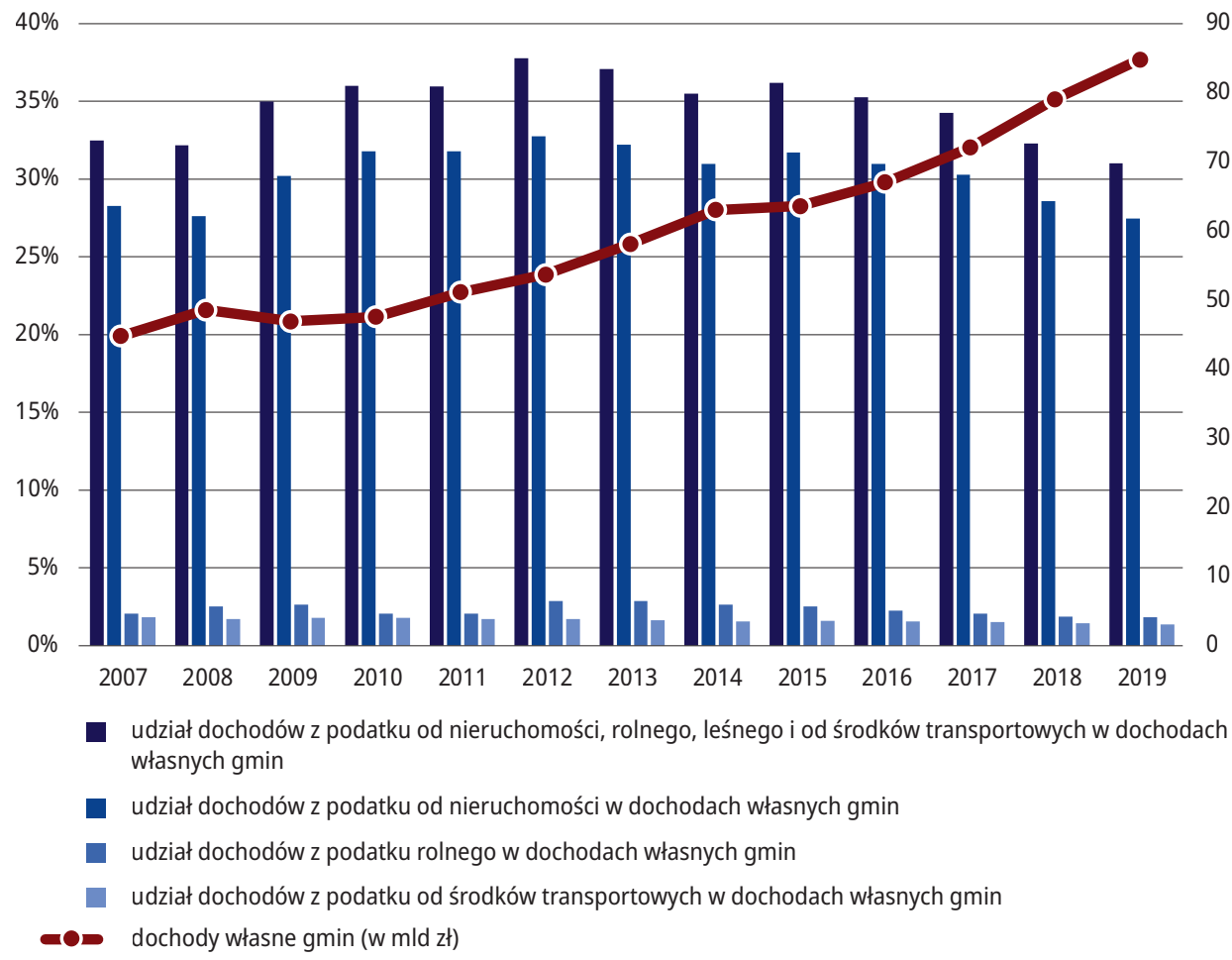

Źródło: opracowanie własne na podstawie danych z aneksu 1.

Analiza dochodów z podatku od nieruchomości w podziale na poszczególne typy gmin pozwala zaobserwować, że w miastach na prawach powiatu udział dochodów z tego podatku w dochodach własnych jest niższy w porównaniu z innymi gminami. Niezależnie od typu gmin zachodzące zmiany przebiegają podobnie (wykres 3).

W przypadku podatku rolnego od 2012 r. udział dochodów z tego źródła w dochodach własnych nieustannie maleje, co wynika ze spadku nominalnych dochodów uzyskiwanych z tego tytułu. Wartość wpływów z podatku rolnego w dochodach własnych poszczególnych typów gmin nie jest zaskakująca, gdyż największy udział dochodów z tego podatku w dochodach własnych notują gminy wiejskie, a w miastach na prawach powiatu oraz gminach miejskich jest on niewielki (wykres 4). 
Wykres 3. Udział dochodów z podatku od nieruchomości w dochodach własnych gmin w latach 2007-2019 (w \%)

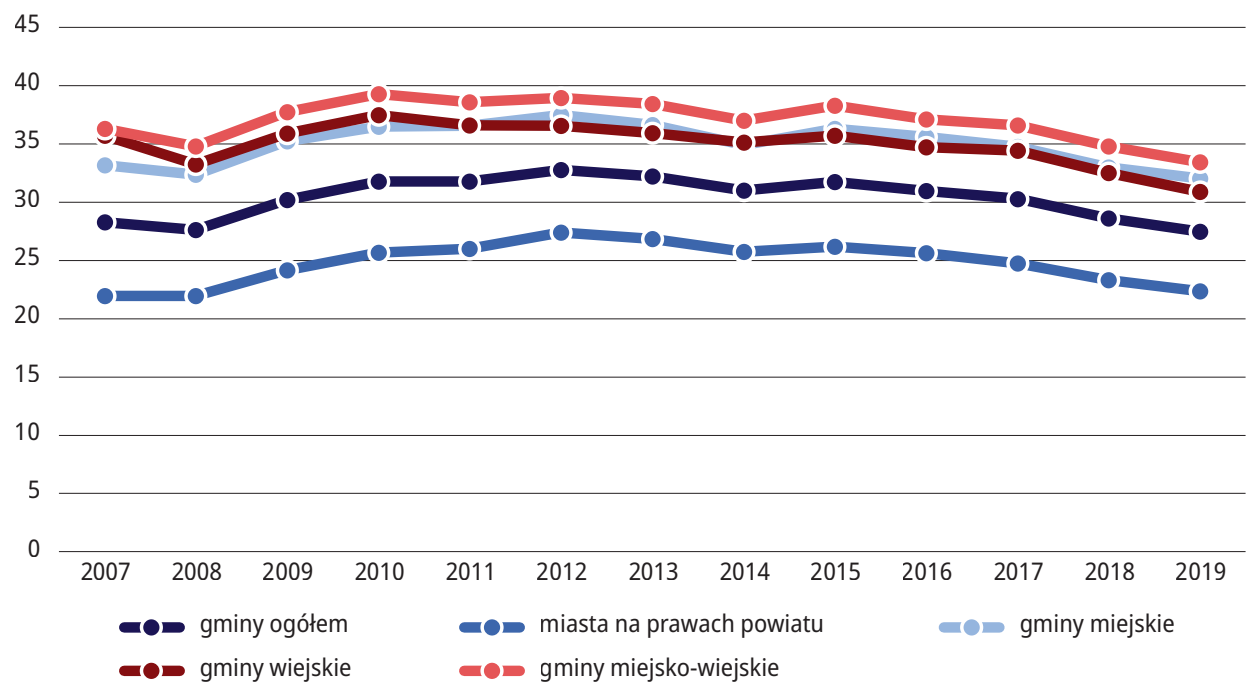

Źródło: opracowanie własne na podstawie danych z aneksu 1.

Wykres 4. Udział dochodów z podatku rolnego w dochodach własnych gmin w latach 20072019 (w \%)

10
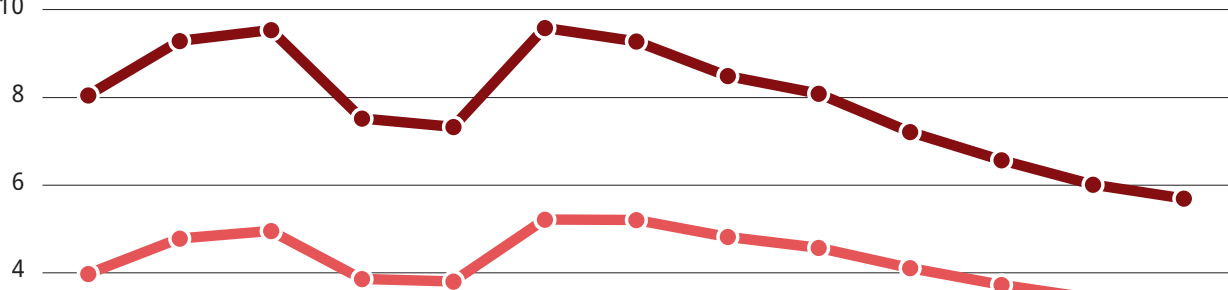

2

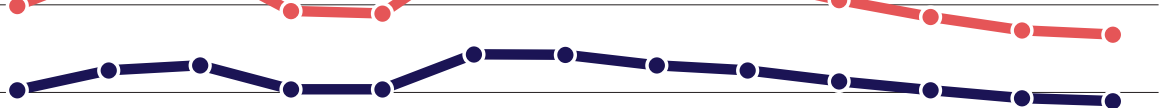

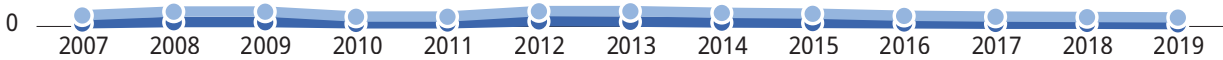
으 gminy ogółem

e- miasta na prawach powiatu

- gminy miejskie

-00 gminy wiejskie

-ob gminy miejsko-wiejskie

Źródło: opracowanie własne na podstawie danych z aneksu 1. 
Tabela 2. Suma dochodów z podatków: od nieruchomości, rolnego, leśnego i od środków transportowych, w przeliczeniu na jednego mieszkańca w latach 2007-2019 (w zł)

\begin{tabular}{|l|l|l|l|l|l|l|l|l|l|l|l|l|l|}
\hline & $\mathbf{2 0 0 7}$ & $\mathbf{2 0 0 8}$ & $\mathbf{2 0 0 9}$ & $\mathbf{2 0 1 0}$ & $\mathbf{2 0 1 1}$ & $\mathbf{2 0 1 2}$ & $\mathbf{2 0 1 3}$ & $\mathbf{2 0 1 4}$ & $\mathbf{2 0 1 5}$ & $\mathbf{2 0 1 6}$ & $\mathbf{2 0 1 7}$ & $\mathbf{2 0 1 8}$ & $\mathbf{2 0 1 9}$ \\
\hline $\begin{array}{l}\text { Gminy } \\
\text { ogółem }\end{array}$ & $\mathbf{3 8 2}$ & $\mathbf{4 1 0}$ & $\mathbf{4 3 0}$ & $\mathbf{4 4 4}$ & $\mathbf{4 7 7}$ & $\mathbf{5 2 7}$ & $\mathbf{5 6 0}$ & $\mathbf{5 8 1}$ & $\mathbf{5 9 9}$ & $\mathbf{6 1 5}$ & $\mathbf{6 4 3}$ & $\mathbf{6 6 5}$ & $\mathbf{6 8 5}$ \\
\hline $\begin{array}{l}\text { Miasta na } \\
\text { prawach } \\
\text { powiatu }\end{array}$ & 428 & 454 & 476 & 505 & 539 & 582 & 608 & 636 & 657 & 675 & 700 & 731 & 748 \\
\hline $\begin{array}{l}\text { Gminy } \\
\text { miejskie }\end{array}$ & 386 & 410 & 428 & 447 & 483 & 520 & 556 & 567 & 578 & 599 & 620 & 640 & 662 \\
\hline $\begin{array}{l}\text { Gminy } \\
\text { wiejskie }\end{array}$ & 325 & 356 & 374 & 376 & 406 & 464 & 501 & 523 & 536 & 552 & 580 & 596 & 617 \\
\hline $\begin{array}{l}\text { Gminy } \\
\text { miejsko- } \\
\text {-wiejskie }\end{array}$ & 382 & 411 & 435 & 440 & 474 & 531 & 568 & 585 & 607 & 619 & 654 & 673 & 697 \\
\hline
\end{tabular}

Źródło: opracowanie własne na podstawie danych z aneksu 1.

Tabela 3. Suma dochodów z podatku od nieruchomości w przeliczeniu na jednego mieszkańca w latach 2007-2019 (w zł)

\begin{tabular}{|l|l|l|l|l|l|l|l|l|l|l|l|l|l|}
\hline & $\mathbf{2 0 0 7}$ & $\mathbf{2 0 0 8}$ & $\mathbf{2 0 0 9}$ & $\mathbf{2 0 1 0}$ & $\mathbf{2 0 1 1}$ & $\mathbf{2 0 1 2}$ & $\mathbf{2 0 1 3}$ & $\mathbf{2 0 1 4}$ & $\mathbf{2 0 1 5}$ & $\mathbf{2 0 1 6}$ & $\mathbf{2 0 1 7}$ & $\mathbf{2 0 1 8}$ & $\mathbf{2 0 1 9}$ \\
\hline $\begin{array}{l}\text { Gminy } \\
\text { ogółem }\end{array}$ & $\mathbf{3 3 2}$ & $\mathbf{3 5 2}$ & $\mathbf{3 7 1}$ & $\mathbf{3 9 2}$ & $\mathbf{4 2 2}$ & $\mathbf{4 5 7}$ & $\mathbf{4 8 7}$ & $\mathbf{5 0 8}$ & $\mathbf{5 2 5}$ & $\mathbf{5 4 1}$ & $\mathbf{5 6 8}$ & $\mathbf{5 8 9}$ & $\mathbf{6 0 7}$ \\
\hline $\begin{array}{l}\text { Miasta na } \\
\text { prawach } \\
\text { powiatu }\end{array}$ & 401 & 428 & 450 & 480 & 514 & 556 & 582 & 610 & 629 & 646 & 671 & 701 & 717 \\
\hline $\begin{array}{l}\text { Gminy } \\
\text { miejskie }\end{array}$ & 360 & 382 & 400 & 421 & 457 & 491 & 527 & 537 & 549 & 569 & 590 & 611 & 632 \\
\hline $\begin{array}{l}\text { Gminy } \\
\text { wiejskie }\end{array}$ & 244 & 256 & 271 & 288 & 310 & 338 & 368 & 390 & 403 & 419 & 447 & 461 & 478 \\
\hline $\begin{array}{l}\text { Gminy } \\
\text { miejsko- } \\
\text {-wiejskie }\end{array}$ & 321 & 338 & 360 & 375 & 403 & 439 & 470 & 488 & 510 & 522 & 556 & 574 & 593 \\
\hline
\end{tabular}

Źródło: opracowanie własne na podstawie danych z aneksu 1.

Nominalne dochody z podatku od środków transportowych w latach 2007-2019 wzrosły w każdym typie gmin. Najmniejsze dochody osiągają z tego tytułu gminy miejskie (ok. $150 \mathrm{mln}$ zł w 2019 r.), natomiast łączne dochody z tego podatku w gminach wiejskich i miastach na prawach powiatu są zbliżone pod względem wartości, ale to w gminach wiejskich nastąpił wyraźny wzrost w porównaniu z 2007 r. Dochody z tego podatku stanowią jednak niecałe 1,5\% udziału w dochodach własnych gmin mimo wzrostu ich nominalnej wartości (wykres 5).

W przeliczeniu na jednego mieszkańca dochody uzyskiwane przez gminy z podatku od nieruchomości, rolnego, leśnego i od środków transportowych wynoszą niecałe 700 zł. Niezależnie od 


\section{Wykres 5. Udział dochodów z podatku od środków transportowych w dochodach własnych} gmin w latach 2007-2019 (w \%)

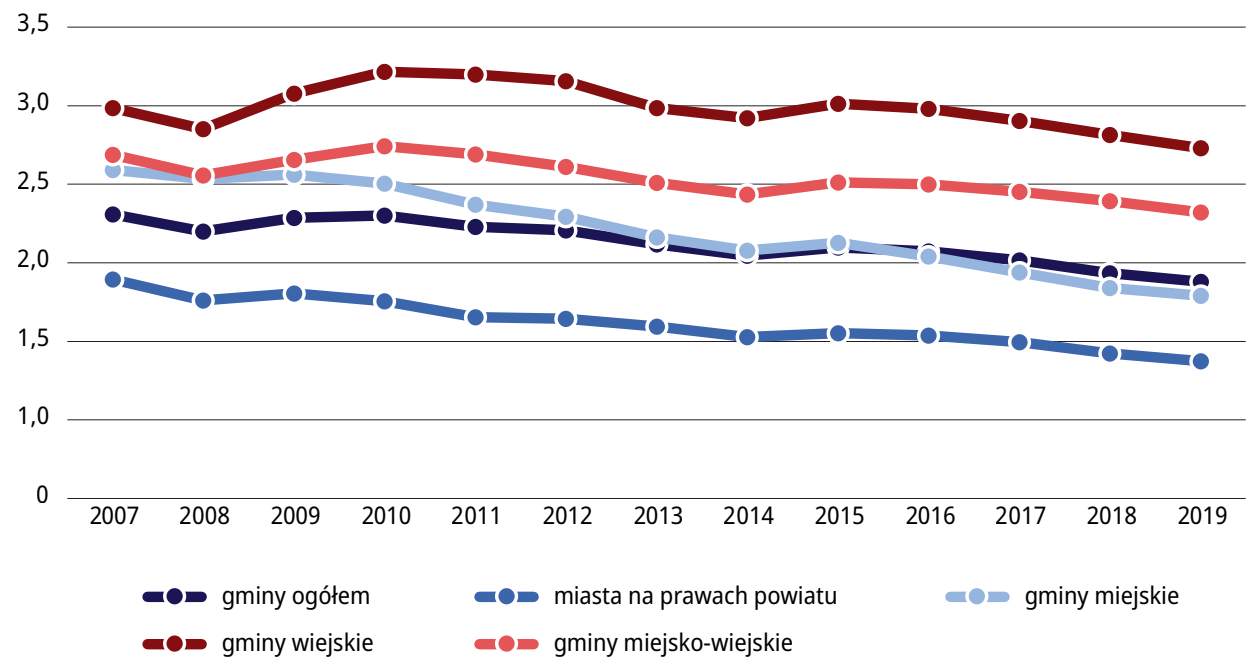

Źródło: opracowanie własne na podstawie danych z aneksu 1.

typu gminy od 2007 r. nastąpił wzrost o ok. 300 zł. W miastach na prawach powiatu i gminach miejsko-wiejskich wzrost był nieco większy (tabela 2).

Zasadniczą część dochodów własnych gmin z tych czterech podatków stanowią wpływy z podatku od nieruchomości. W przeliczeniu na mieszkańca najwyższe dochody czerpią miasta na prawach powiatu, a najniższe - gminy wiejskie. Średnio na jednego mieszkańca gminy przypada 607 zł dochodów z podatku od nieruchomości (tabela 3).

\section{Zróżnicowanie lokalnej polityki podatkowej gmin i jej fiskalne skutki}

Gminy mogą - o czym pisano w pierwszej części artykułu - stosować wobec wybranych podatków lokalnych instrumenty władztwa podatkowego, przede wszystkim: obniżki stawek podatkowych, ulgi i zwolnienia podatkowe, umorzenia zobowiązań podatkowych lub rozłożenie spłat należnego podatku na raty. W największym stopniu preferencje były stosowane w gminach wiejskich - udział preferencji w ich dochodach własnych stanowił w 2019 r. aż 25\% (wykres 6). Najmniejsze straty z tytułu stosowanych preferencji ponoszą miasta na prawach powiatu (7,35\%). Udział preferencji w wykonanych dochodach w gminach miejskich jest prawie identyczny ze średnią dla wszystkich gmin.

Stosowane preferencje w podatkach: od nieruchomości, rolnym, leśnym i od środków transportowych, w ujęciu kwotowym w przeliczeniu na jednego mieszkańca rosły w latach 2007-2019 i osiągnęły w 2019 r. średnio 114 zł. Najniższe kwotowo preferencje były stosowane w miastach na prawach powiatu, a najwyższe - w gminach wiejskich (średnio 155 zł na jednego miesz- 
Wykres 6. Preferencje w podatkach: od nieruchomości, rolnym, leśnym i od środków transportowych, w relacji do wykonanych dochodów z tych podatków w latach 2007-2019 (w \%)

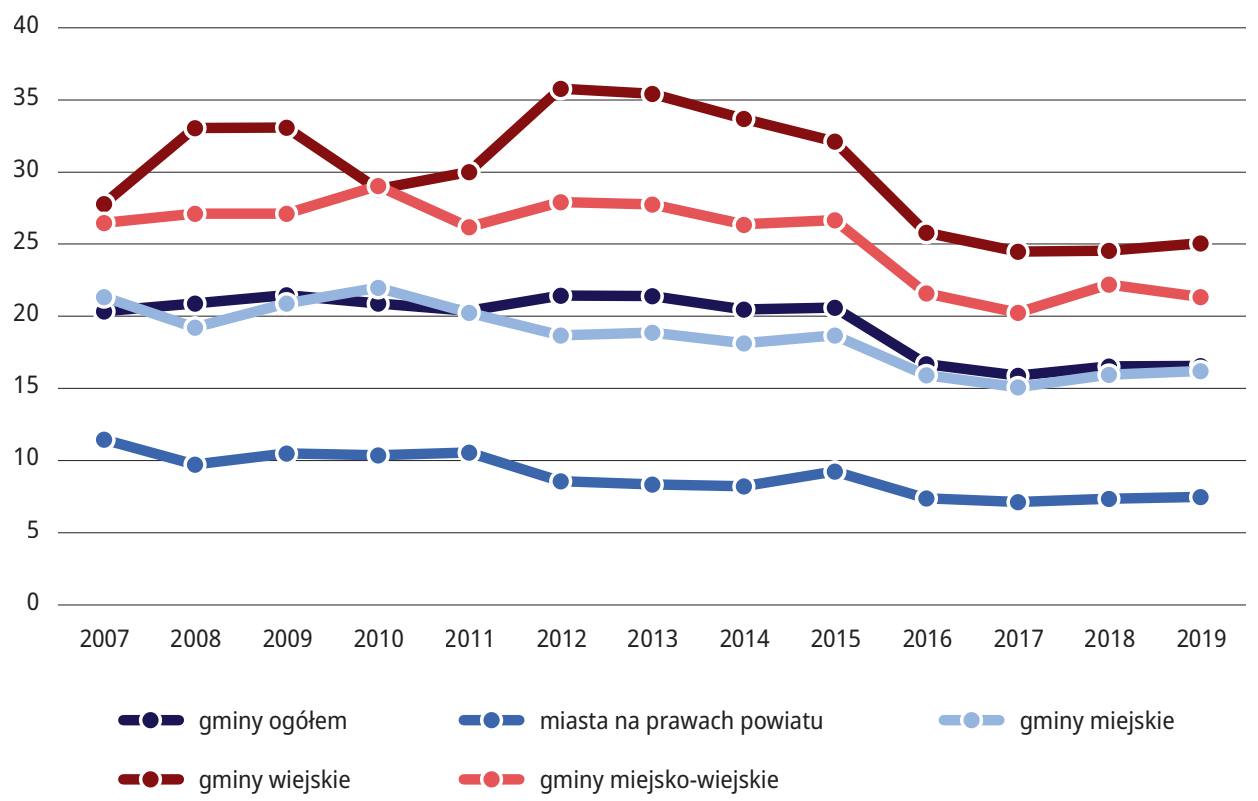

Źródło: opracowanie własne na podstawie danych z aneksów 1 i 2.

Tabela 4. Preferencje w podatkach: od nieruchomości, rolnym, leśnym i od środków transportowych, w przeliczeniu na jednego mieszkańca w latach 2007-2019 (w zł)

\begin{tabular}{|l|c|c|c|c|c|c|c|c|c|c|c|c|c|}
\hline & $\mathbf{2 0 0 7}$ & $\mathbf{2 0 0 8}$ & $\mathbf{2 0 0 9}$ & $\mathbf{2 0 1 0}$ & $\mathbf{2 0 1 1}$ & $\mathbf{2 0 1 2}$ & $\mathbf{2 0 1 3}$ & $\mathbf{2 0 1 4}$ & $\mathbf{2 0 1 5}$ & $\mathbf{2 0 1 6}$ & $\mathbf{2 0 1 7}$ & $\mathbf{2 0 1 8}$ & $\mathbf{2 0 1 9}$ \\
\hline $\begin{array}{l}\text { Gminy } \\
\text { ogółem }\end{array}$ & $\mathbf{7 8}$ & $\mathbf{8 6}$ & $\mathbf{9 2}$ & $\mathbf{9 3}$ & $\mathbf{9 7}$ & $\mathbf{1 1 3}$ & $\mathbf{1 2 0}$ & $\mathbf{1 1 9}$ & $\mathbf{1 2 3}$ & $\mathbf{1 0 3}$ & $\mathbf{1 0 2}$ & $\mathbf{1 1 0}$ & $\mathbf{1 1 4}$ \\
\hline $\begin{array}{l}\text { Miasta na } \\
\text { prawach } \\
\text { powiatu }\end{array}$ & 49 & 44 & 50 & 52 & 57 & 50 & 51 & 52 & 61 & 50 & 50 & 54 & 56 \\
\hline $\begin{array}{l}\text { Gminy } \\
\text { miejskie }\end{array}$ & 82 & 79 & 89 & 98 & 98 & 97 & 105 & 103 & 108 & 95 & 93 & 102 & 107 \\
\hline $\begin{array}{l}\text { Gminy } \\
\text { wiejskie }\end{array}$ & 90 & 118 & 124 & 108 & 122 & 166 & 177 & 176 & 172 & 142 & 142 & 146 & 155 \\
\hline $\begin{array}{l}\text { Gminy } \\
\text { miejsk- } \\
\text {-wiejskie }\end{array}$ & 101 & 112 & 118 & 128 & 124 & 148 & 158 & 154 & 162 & 134 & 132 & 150 & 149 \\
\hline
\end{tabular}

Źródło: opracowanie własne na podstawie danych z aneksów 1 i 2. 
Wykres 7. Udział stosowanych obniżek, ulg, zwolnień, umorzeń i rat w podatku od nieruchomości w kontekście sumy stosowanych obniżek, ulg, zwolnień, umorzeń i rat w podatkach: od nieruchomości, rolnym, leśnym i od środków transportowych, w latach 2007-2019 (w \%)

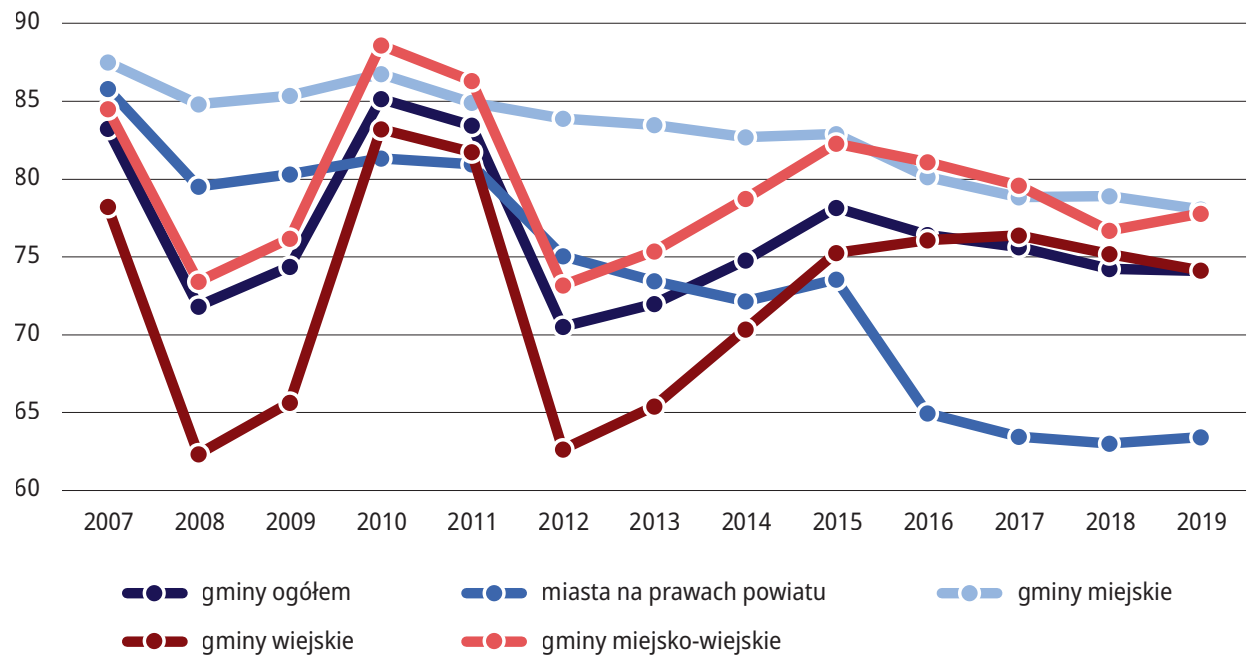

Źródło: opracowanie własne na podstawie danych z aneksu 2.

kańca). Warto jednak zauważyć, że w 2007 r. największą kwotę preferencji oferowały gminy miejsko-wiejskie.

Największy wpływ na obniżenie dochodów własnych gmin czerpanych z czterech badanych podatków miały preferencje podatkowe stosowane w podatku od nieruchomości (wykres 7). W przypadku gmin wiejskich i miejsko-wiejskich zmiany przebiegały podobnie, z widocznym wzrostem wartości stosowanych preferencji w latach 2010-2011. Miasta na prawach powiatu niezbyt chętnie stosują preferencje podatkowe, a udział takich preferencji spada w ostatnich latach (podobnie jak ich wartość nominalna). Jednocześnie w badanym okresie odnotowano wzrost dochodów podatkowych z podatku od nieruchomości w przypadku miast na prawach powiatu (z 5,1 mld zł w 2007 r. do 9 mld zł w 2019 r.).

Udział preferencji w podatku rolnym był bardzo zróżnicowany w przypadku gmin wiejskich (5-30\%) i miejsko-wiejskich (2-17\%). Przykładowo w gminach wiejskich nastąpił spadek o ok. 23\% w latach 2008-2010 - do blisko 4\% w 2010 r. Widoczne zmniejszenie się udziału preferencji w podatku rolnym pokryło się z okresem spadku dochodów nominalnych z tego podatku, który wystąpił w latach 2010-2011. W gminach miejskich i miastach na prawach powiatu udziały utrzymywały się na bardzo niskim poziomie (poniżej 1\%).

W obu analizowanych podatkach od majątku nieruchomego malejący udział stosowanych preferencji w kolejnych latach znajduje odzwierciedlenie w rosnącym znaczeniu preferencji stosowanych w podatku od środków transportowych (wykres 9). Istotny wzrost nastąpił w przy- 
Wykres 8. Udział stosowanych obniżek, ulg, zwolnień, umorzeń i rat w podatku rolnym w kontekście sumy stosowanych obniżek, ulg, zwolnień, umorzeń i rat w podatkach: od nieruchomości, rolnym, leśnym i od środków transportowych, w latach 2007-2019 (w \%)

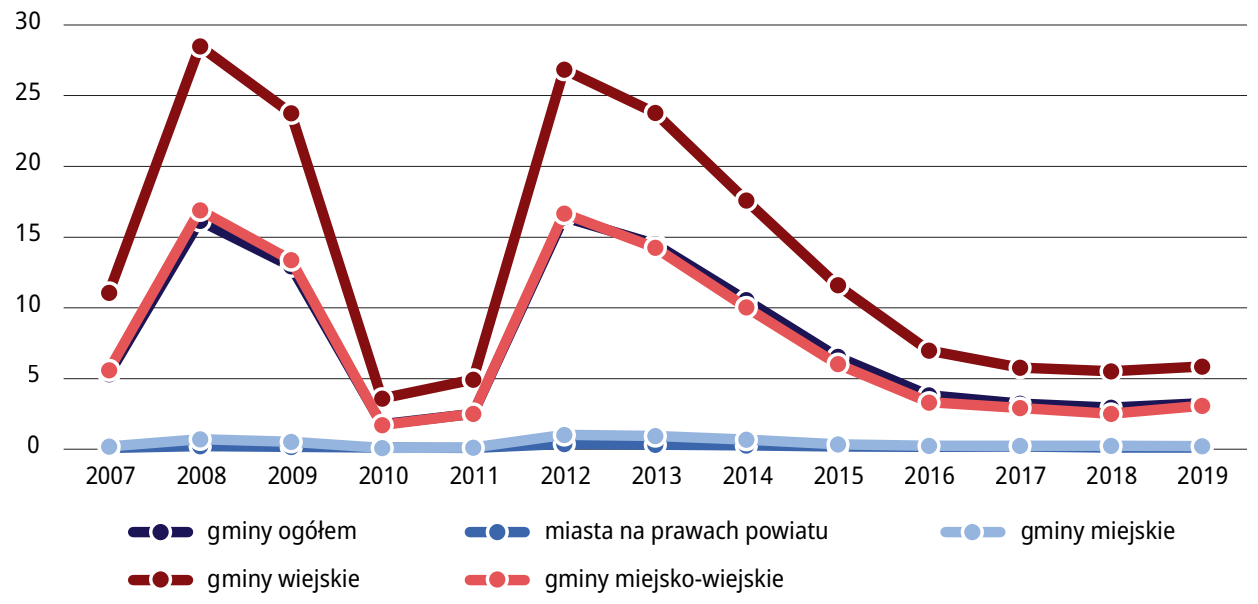

Źródło: opracowanie własne na podstawie danych z aneksu 2.

Wykres 9. Udział stosowanych obniżek, ulg, zwolnień, umorzeń i rat w podatku od środków transportowych w kontekście sumy stosowanych obniżek, ulg, zwolnień, umorzeń i rat w podatkach: od nieruchomości, rolnym, leśnym i od środków transportowych, w latach 2007-2019 (w \%)

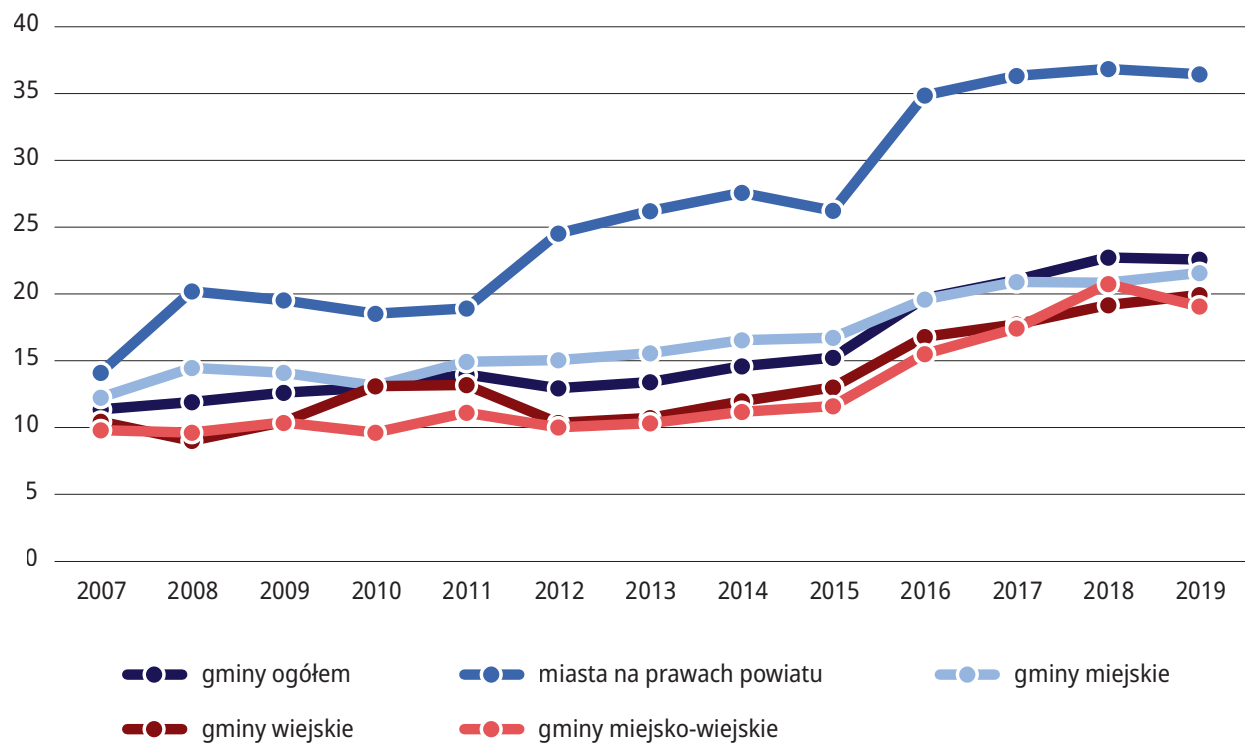


Wykres 10. Struktura preferencji w podatku od nieruchomości w latach 2007-2019 (w \%)

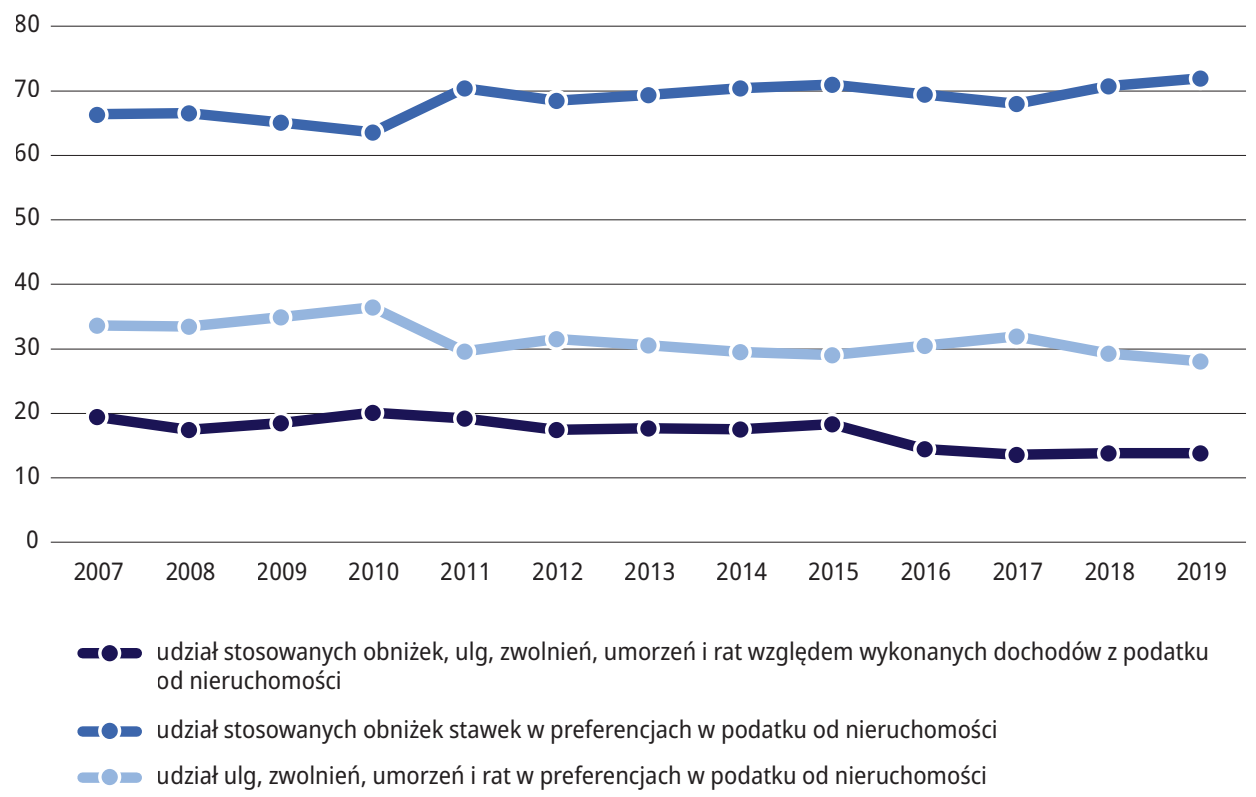

Źródło: opracowanie własne na podstawie danych z aneksów 1 i 2.

Tabela 5. Udział obniżek stawek w podatku od nieruchomości w wykonanych dochodach z tego podatku w latach 2007-2019 (w \%)

\begin{tabular}{|l|c|c|c|c|c|c|c|c|c|c|c|c|c|}
\hline & $\mathbf{2 0 0 7}$ & $\mathbf{2 0 0 8}$ & $\mathbf{2 0 0 9}$ & $\mathbf{2 0 1 0}$ & $\mathbf{2 0 1 1}$ & $\mathbf{2 0 1 2}$ & $\mathbf{2 0 1 3}$ & $\mathbf{2 0 1 4}$ & $\mathbf{2 0 1 5}$ & $\mathbf{2 0 1 6}$ & $\mathbf{2 0 1 7}$ & $\mathbf{2 0 1 8}$ & $\mathbf{2 0 1 9}$ \\
\hline $\begin{array}{l}\text { Gminy } \\
\text { ogółem }\end{array}$ & $\mathbf{1 2 , 9}$ & $\mathbf{1 1 , 6}$ & $\mathbf{1 2 , 1}$ & $\mathbf{1 2 , 8}$ & $\mathbf{1 3 , 5}$ & $\mathbf{1 1 , 9}$ & $\mathbf{1 2 , 3}$ & $\mathbf{1 2 , 3}$ & $\mathbf{1 3 , 0}$ & $\mathbf{1 0 , 1}$ & $\mathbf{9 , 2}$ & $\mathbf{9 , 8}$ & $\mathbf{1 0 , 0}$ \\
\hline $\begin{array}{l}\text { Miasta na } \\
\text { prawach } \\
\text { powiatu }\end{array}$ & 6,2 & 4,9 & 5,1 & 5,1 & 5,8 & $\mathbf{3 , 9}$ & $\mathbf{3 , 7}$ & $\mathbf{3 , 8}$ & $\mathbf{4 , 2}$ & $\mathbf{2 , 7}$ & $\mathbf{2 , 4}$ & $\mathbf{2 , 9}$ & $\mathbf{3 , 1}$ \\
\hline $\begin{array}{l}\text { Gminy } \\
\text { miejskie }\end{array}$ & 13,2 & 11,9 & 12,6 & 13,3 & 13,6 & 12,1 & 12,3 & 12,1 & 12,5 & 10,2 & 9,3 & 9,9 & 10,0 \\
\hline $\begin{array}{l}\text { Gminy } \\
\text { wiejskie }\end{array}$ & 19,9 & 18,9 & 19,6 & 20,6 & 21,9 & 20,8 & 21,3 & 21,7 & 22,2 & 17,9 & 16,4 & 16,8 & 16,9 \\
\hline $\begin{array}{l}\text { Gminy } \\
\text { miejsk- } \\
\text {-wiejskie }\end{array}$ & 18,7 & 17,1 & 17,2 & 19,2 & 19,6 & 17,8 & 18,8 & 18,6 & 20,0 & 15,2 & 13,8 & 14,8 & 14,7 \\
\hline
\end{tabular}

Źródło: opracowanie własne na podstawie danych z aneksów 1 i 2. 
Tabela 6. Preferencje w podatku od nieruchomości w przeliczeniu na jednego mieszkańca w latach 2007-2019 (w zł)

\begin{tabular}{|c|c|c|c|c|c|c|c|c|c|c|c|c|c|}
\hline & 2007 & 2008 & 2009 & 2010 & 2011 & 2012 & 2013 & 2014 & 2015 & 2016 & 2017 & 2018 & 2019 \\
\hline \multicolumn{14}{|c|}{ Obniżka stawek podatkowych } \\
\hline $\begin{array}{l}\text { Gminy } \\
\text { ogółem }\end{array}$ & 42,9 & 40,9 & 44,7 & 50,2 & 57,1 & 54,5 & 59,9 & 62,7 & 68,4 & 54,5 & 52,5 & 57,7 & 60,6 \\
\hline $\begin{array}{l}\text { Miasta na } \\
\text { prawach } \\
\text { powiatu }\end{array}$ & 24,7 & 21,0 & 23,0 & 24,4 & 29,9 & 21,9 & 21,6 & 22,9 & 26,3 & 17,5 & 16,4 & 20,3 & 22,6 \\
\hline $\begin{array}{l}\text { Gminy } \\
\text { miejskie }\end{array}$ & 47,3 & 45,3 & 50,6 & 56,0 & 62,0 & 59,6 & 64,8 & 65,1 & 68,7 & 58,0 & 54,6 & 60,5 & 63,3 \\
\hline $\begin{array}{l}\text { Gminy } \\
\text { wiejskie }\end{array}$ & 48,5 & 48,5 & 53,3 & 59,5 & 67,8 & 70,1 & 78,3 & 84,5 & 89,4 & 74,9 & 73,3 & 77,3 & 80,8 \\
\hline $\begin{array}{l}\text { Gminy } \\
\text { miejsko- } \\
\text {-wiejskie }\end{array}$ & 59,9 & 57,9 & 61,9 & 71,8 & 79,2 & 78,1 & 88,5 & 90,8 & 102,1 & 79,5 & 76,6 & 84,6 & 87,2 \\
\hline \multicolumn{14}{|c|}{ Preferencje inne niż obniżka stawek podatkowych } \\
\hline $\begin{array}{l}\text { Gminy } \\
\text { ogółem }\end{array}$ & 21,8 & 20,6 & 24,0 & 28,8 & 24,0 & 25,1 & 26,4 & 26,3 & 28,0 & 24,0 & 24,7 & 23,9 & 23,6 \\
\hline $\begin{array}{l}\text { Miasta na } \\
\text { prawach } \\
\text { powiatu }\end{array}$ & 17,5 & 14,1 & 17,1 & 18,1 & 16,1 & 15,5 & 15,6 & 14,8 & 18,4 & 14,8 & 15,2 & 13,6 & 12,9 \\
\hline $\begin{array}{l}\text { Gminy } \\
\text { miejskie }\end{array}$ & 24,6 & 21,6 & 25,7 & 29,3 & 21,1 & 21,9 & 22,9 & 19,9 & 20,9 & 18,4 & 19,0 & 20,1 & 20,4 \\
\hline $\begin{array}{l}\text { Gminy } \\
\text { wiejskie }\end{array}$ & 22,2 & 24,9 & 27,9 & 30,8 & 31,7 & 33,8 & 37,8 & 39,5 & 40,2 & 33,4 & 35,2 & 32,7 & 33,7 \\
\hline $\begin{array}{l}\text { Gminy } \\
\text { miejsko- } \\
\text {-wiejskie }\end{array}$ & 25,6 & 24,0 & 28,0 & 41,3 & 27,8 & 30,3 & 30,2 & 30,7 & 31,2 & 29,0 & 28,9 & 30,0 & 28,4 \\
\hline
\end{tabular}

Źródło: opracowanie własne na podstawie danych z aneksów 1 i 2.

padku miast na prawach powiatu (z 15\% do ponad 35\%). W pozostałych typach gmin udział preferencji wzrósł średnio o ok. 10 p.p.

Preferencje stosowane w podatku od nieruchomości stanowiły niecałe $20 \%$ względem uzyskiwanych dochodów z tytułu tego podatku (wykres 10). Zasadniczą częścią zastosowanych preferencji były obniżki stawek podatkowych (ok. 70\% wartości preferencji w analizowanych latach).

Wartość obniżek stawek podatku od nieruchomości na przestrzeni analizowanych lat malała i w 2019 r. stanowiła tylko 10\% dochodów z tego podatku (tabela 5), podczas gdy w 2007 r. było to $12,9 \%$. Największy spadek wartości obniżek stawek wobec wykonanych dochodów wystąpił w gminach miejsko-wiejskich (4\%).

W przypadku przeliczenia wartości preferencji na jednego mieszkańca widać jednak, że ustalona kwota rosła w kolejnych latach (tabela 6). Jedynie w miastach na prawach powiatu wystąpiły spadki - w zakresie zarówno obniżek stawek podatkowych, jak i pozostałych preferencji. 
Wykres 11. Struktura preferencji w podatku rolnym w latach 2007-2019 (w \%)

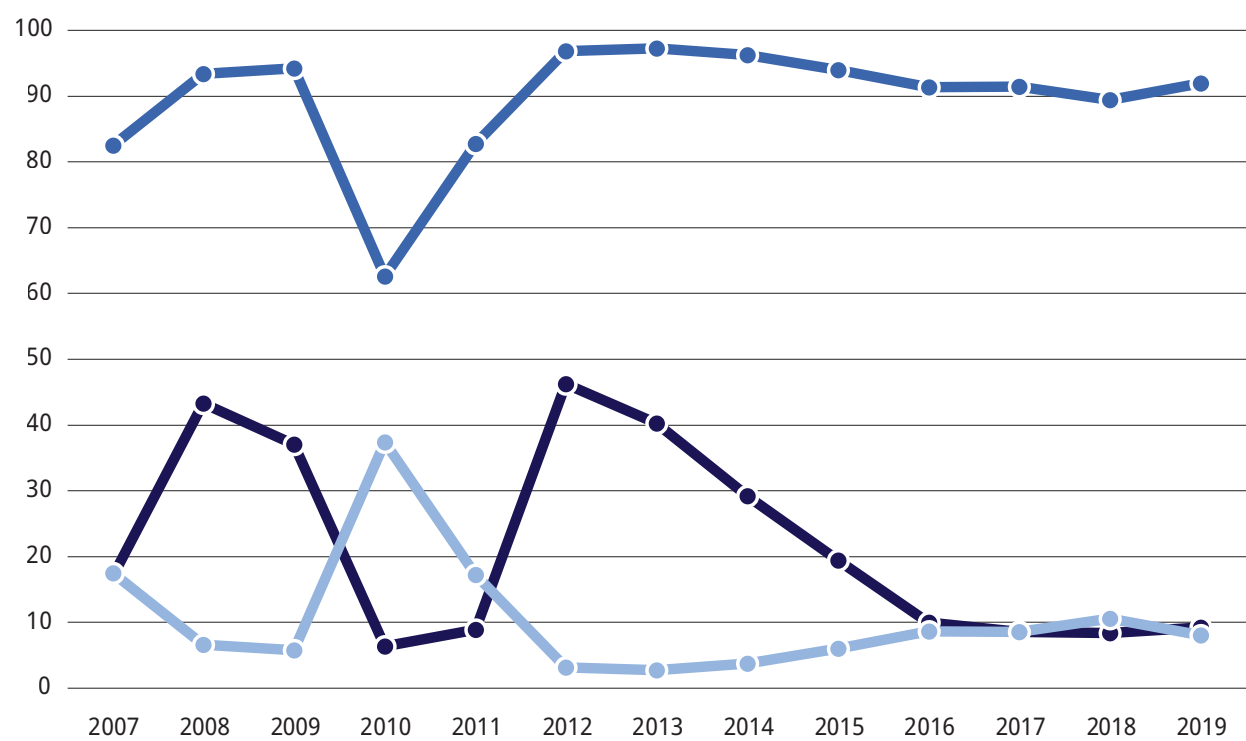

-0- udział stosowanych obniżek, ulg, zwolnień, umorzeń i rat względem wykonanych dochodów w podatku rolnym

-O udział stosowanych obniżek stawek w preferencjach w podatku rolnym

-O udział ulg, zwolnień, umorzeń i rat w preferencjach w podatku rolnym

Źródło: opracowanie własne na podstawie danych z aneksów 1 i 2.

Tabela 7. Udział obniżek stawek w podatku rolnym w wykonanych dochodach z tego podatku w latach 2007-2019 (w \%)

\begin{tabular}{|l|c|c|c|c|c|c|c|c|c|c|c|c|c|}
\hline & $\mathbf{2 0 0 7}$ & $\mathbf{2 0 0 8}$ & $\mathbf{2 0 0 9}$ & $\mathbf{2 0 1 0}$ & $\mathbf{2 0 1 1}$ & $\mathbf{2 0 1 2}$ & $\mathbf{2 0 1 3}$ & $\mathbf{2 0 1 4}$ & $\mathbf{2 0 1 5}$ & $\mathbf{2 0 1 6}$ & $\mathbf{2 0 1 7}$ & $\mathbf{2 0 1 8}$ & $\mathbf{2 0 1 9}$ \\
\hline $\begin{array}{l}\text { Gminy } \\
\text { ogółem }\end{array}$ & $\mathbf{1 4 , 1}$ & $\mathbf{4 0 , 4}$ & $\mathbf{3 4 , 9}$ & $\mathbf{4 , 0}$ & $\mathbf{7 , 3}$ & $\mathbf{4 4 , 8}$ & $\mathbf{3 9 , 1}$ & $\mathbf{2 8 , 2}$ & $\mathbf{1 8 , 3}$ & $\mathbf{9 , 1}$ & $\mathbf{7 , 8}$ & $\mathbf{7 , 5}$ & $\mathbf{8 , 5}$ \\
\hline $\begin{array}{l}\text { Miasta na } \\
\text { prawach } \\
\text { powiatu }\end{array}$ & 1,8 & 3,4 & 2,9 & 1,5 & 2,4 & $\mathbf{7 , 5}$ & $\mathbf{6 , 5}$ & $\mathbf{5 , 4}$ & $\mathbf{5 , 6}$ & $\mathbf{3 , 9}$ & $\mathbf{3 , 5}$ & $\mathbf{3 , 3}$ & $\mathbf{3 , 5}$ \\
\hline $\begin{array}{l}\text { Gminy } \\
\text { miejskie }\end{array}$ & 4,7 & 12,7 & 11,1 & 2,0 & 3,5 & 20,3 & 19,2 & 14,5 & 8,2 & 5,6 & 5,5 & 5,0 & 5,8 \\
\hline $\begin{array}{l}\text { Gminy } \\
\text { wiejskie }\end{array}$ & 15,2 & 43,9 & 38,5 & 4,3 & 8,0 & 48,8 & 43,2 & 31,7 & 20,6 & 10,5 & 8,8 & 8,6 & 9,6 \\
\hline $\begin{array}{l}\text { Gminy } \\
\text { miejsko- } \\
\text {-wiejskie }\end{array}$ & 13,0 & 37,6 & 31,2 & 3,6 & 6,4 & 40,7 & 34,4 & 23,4 & 15,0 & 7,0 & 6,2 & 5,8 & 6,9 \\
\hline
\end{tabular}

Źródło: opracowanie własne na podstawie danych z aneksów 1 i 2. 
Wykres 12. Struktura preferencji w podatku od środków transportowych w latach 2007-2019 (w \%)

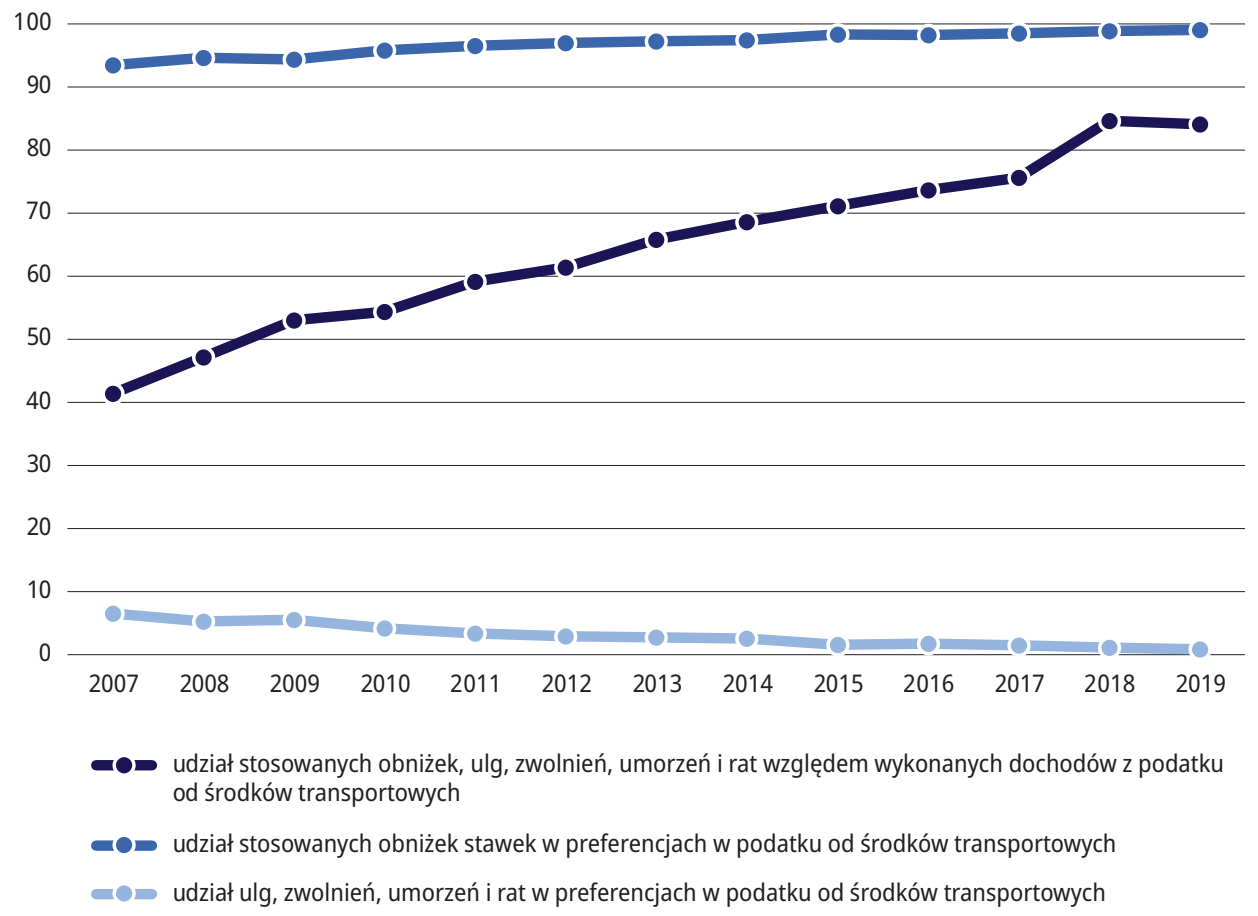

Źródło: opracowanie własne na podstawie danych z aneksów 1 i 2.

Tabela 8. Udział obniżek stawek w podatku od środków transportowych w wykonanych dochodach z tego podatku w latach 2007-2019 (w \%)

\begin{tabular}{|l|l|l|l|l|l|l|l|l|l|l|l|l|l|}
\hline & $\mathbf{2 0 0 7}$ & $\mathbf{2 0 0 8}$ & $\mathbf{2 0 0 9}$ & $\mathbf{2 0 1 0}$ & $\mathbf{2 0 1 1}$ & $\mathbf{2 0 1 2}$ & $\mathbf{2 0 1 3}$ & $\mathbf{2 0 1 4}$ & $\mathbf{2 0 1 5}$ & $\mathbf{2 0 1 6}$ & $\mathbf{2 0 1 7}$ & $\mathbf{2 0 1 8}$ & $\mathbf{2 0 1 9}$ \\
\hline $\begin{array}{l}\text { Gminy } \\
\text { ogółem }\end{array}$ & $\mathbf{3 8 , 7}$ & $\mathbf{4 4 , 7}$ & $\mathbf{5 0 , 1}$ & $\mathbf{5 2 , 1}$ & $\mathbf{5 7 , 1}$ & $\mathbf{5 9 , 6}$ & $\mathbf{6 4 , 0}$ & $\mathbf{6 6 , 9}$ & $\mathbf{6 9 , 9}$ & $\mathbf{7 2 , 3}$ & $\mathbf{7 4 , 5}$ & $\mathbf{8 3 , 6}$ & $\mathbf{8 3 , 3}$ \\
\hline $\begin{array}{l}\text { Miasta na } \\
\text { prawach } \\
\text { powiatu }\end{array}$ & 25,5 & 34,8 & 38,3 & 40,2 & 46,1 & 51,7 & 55,1 & 58,4 & 62,7 & 65,2 & 66,5 & 70,8 & 72,4 \\
\hline $\begin{array}{l}\text { Gminy } \\
\text { miejskie }\end{array}$ & 42,5 & 45,8 & 51,2 & 54,0 & 61,0 & 60,1 & 66,3 & 68,3 & 71,9 & 74,9 & 78,7 & 84,7 & 90,0 \\
\hline $\begin{array}{l}\text { Gminy } \\
\text { wiejskie }\end{array}$ & 51,2 & 54,3 & 61,9 & 64,6 & 67,1 & 67,5 & 72,1 & 76,0 & 77,5 & 78,0 & 78,8 & 84,0 & 88,2 \\
\hline $\begin{array}{l}\text { Gminy } \\
\text { miejsk- } \\
\text {-wiejskie }\end{array}$ & 47,8 & 50,7 & 55,8 & 54,2 & 57,7 & 60,1 & 64,1 & 65,6 & 68,6 & 72,6 & 76,8 & 98,6 & 86,9 \\
\hline
\end{tabular}

Źródło: opracowanie własne na podstawie danych z aneksów 1 i 2. 
W podatku rolnym spadek dochodów gmin z tytułu stosowanych preferencji wyniósł w całym okresie średnio 22\% dochodów z podatku rolnego, a w ostatnich latach - ok. $9 \%$ (wykres 11). Obniżki stawek podatku rolnego stanowią ponad 90\% stosowanych preferencji. Jedynie w 2010 r. można dostrzec wzrost udziału preferencji innych niż obniżka stawek.

W wykonanych dochodach z podatku rolnego obniżki stawek stanowiły w 2019 r. średnio $8,5 \%$. Udziały obniżek stawek w poszczególnych rodzajach gmin oscylowały w ostatnich latach (2016-2019) wokół zbliżonych wartości - najwyższy występował w gminach wiejskich (ok. 9\%). Gminy niechętnie przyznają preferencje w tym podatku, co prawdopodobnie wynika z braku wzrostu dochodów podatkowych z tego tytułu w ostatnich latach (aneks 1).

Dane dotyczące podatku od środków transportowych znacznie się różnią na tle pozostałych podatków. W analizowanych latach stale rośnie udział preferencji w dochodach uzyskiwanych z tego tytułu (wykres 12). W 2019 r. dochody gmin zmniejszyły się o 84\% z uwagi na stosowane obniżki stawek.

Największe obniżki są stosowane przez gminy miejskie, które tracą z ich powodu ok. 90\% dochodów (2019 r.). Najrzadziej korzystają z prawa do stosowania preferencji miasta na prawach powiatu (72,4\%), choć w ich przypadku udział obniżek w dochodach w badanym okresie (2007-2019) wzrósł prawie trzykrotnie. W tym samym okresie w pozostałych gminach nastąpił niemal dwukrotny wzrost względem poziomu z 2007 r.

\section{Podsumowanie}

Przedstawiona analiza oddziaływania gmin na podatki lokalne oraz roli, jaką te podatki odgrywają jako źródło dochodów gmin, potwierdza wnioski innych badaczy. Nie ma wątpliwości, że gminy korzystają z licznych źródeł podatków, a także nieuwzględnionych w artykule opłat lokalnych. Jednak ich udział w dochodach własnych w okresie objętym analizą, zwłaszcza w ostatnich latach, malał. Przyczyny należy upatrywać m.in. w poszerzeniu zakresu zadań gmin finansowanych z subwencji oraz w zwiększeniu udziału w podatkach państwowych, a także w zmianach w konstrukcji podatków lokalnych i skutkach wykorzystania prerogatyw władztwa podatkowego organów lokalnych. Zaprezentowane w artykule zmiany w kształtowaniu się wybranych wielkości charakteryzujących samodzielność dochodową gmin wskazują, że - zwłaszcza w ostatnich latach - sukcesywnie zmniejszała się autonomia finansowa gmin. Największe znaczenie w dochodach własnych spośród podatków lokalnych, względem których gminy posiadają władztwo podatkowe, ma podatek od nieruchomości. W 2019 r. udział dochodów z tego podatku stanowił $27,48 \%$ dochodów własnych. Pozostałe podatki w znikomym stopniu wpłynęły na wysokość uzyskanych dochodów. Ogólnie jednak rosną dochody własne gmin, ale dzięki wykorzystaniu innych źródeł niż omawiane podatki. Znaczne pogorszenie wskaźników analizowanych w części empirycznej opracowania zaobserwowano w odniesieniu do poszczególnych rodzajów gmin. Dane sumaryczne z badanego okresu wskazują przy tym, że omawiane podatki największe znaczenie mają dla budżetów gmin wiejskich i miejsko-wiejskich, najmniejsze zaś dla miast na prawach powiatu, w których ważniejsze są inne kategorie dochodowe. 
Władztwo podatkowe gmin w Polsce jest znacznie ograniczone i sprowadza się do określania wysokości stawek opisanych w artykule podatków lokalnych w ustawowo wyznaczonych granicach i stosowania preferencji podatkowych (przede wszystkim zwolnień przedmiotowych innych niż zawarte w ustawach). A zatem gminy nie mają pełnej swobody kształtowania wysokości stawki żadnego lokalnego podatku. Ponadto w niektórych podatkach (np. w podatku od środków transportowych) w przepisach odpowiedniej ustawy zawarto wymóg określenia wysokości stawki w granicach minimalnych. W przypadku większości podatków lokalnych w regulujących je ustawach przyjęto rozbudowany katalog zwolnień i ulg (np. w podatku rolnym), co z jednej strony ogranicza dochody gmin, z drugiej zaś minimalizuje wykorzystanie innych niż obniżanie górnych stawek podatkowych instrumentów władztwa podatkowego.

Utrata dochodów przez gminy z powodu stosowania preferencji podatkowych w podatku od nieruchomości, podatku rolnym, podatku leśnym i podatku od środków transportowych w 2019 r. stanowiła średnio 16,57\% dochodów uzyskiwanych z tych podatków. W zakresie podatku od nieruchomości była to strata w wysokości 13,86\%, w podatku rolnym - 9,25\%, a w podatku od środków transportowych - 84,12\%. Spośród preferencji gminy najchętniej wybierają obniżki stawek podatkowych, co w przypadku podatku od środków transportowych uszczupliło dochody z tego tytułu o 83,33\% w 2019 r. (90\% dla gmin miejskich).

Polityka podatkowa polskich gmin jest silnie zróżnicowana w zależności od m.in. rodzaju jednostki lokalnej i jej potencjału podatkowego (bazy: mieszkaniowa, handlowa, przemysłowa). Gminy miejskie (przede wszystkim miasta na prawach powiatu) uchwalały stawki wyższe niż w pozostałych jednostkach i prowadziły restrykcyjną politykę podatkową. Kierowały się zatem celem fiskalnym. W gminach mniejszych, głównie wiejskich oraz miejsko-wiejskich, zdecydowanie częściej obniżano stawki podatkowe, prawdopodobnie by stymulować rozwój gospodarki lokalnej (polepszenie sytuacji mieszkańców i przedsiębiorstw). W 2019 r. w gminach wiejskich obniżka stawek podatkowych stanowiła średnio 19,41\% wykonanych dochodów, w gminach miejsko-wiejskich - 17,14\%, a w gminach miejskich - 13,07\%. W miastach na prawach powiatu obniżki stawek stanowiły tylko 5,74\% wykonanych dochodów z tych podatków. Dla całego analizowanego okresu (lata 2007-2019) średnia strata wyniosła 14,6\%, z czego w przypadku miast na prawach powiatu - 6,15\%, gmin miejskich - 14,13\%, gmin miejsko-wiejskich - 19,5\%, a gmin wiejskich $-22,6 \%$.

Polityka podatkowa jest zależna również od rodzaju podatku lokalnego. W gminach największe znaczenie ma podatek od nieruchomości i to na nim koncentrowała się uwaga lokalnych decydentów. Polityka podatkowa w zakresie tego podatku była przewidywalna, a jej bezpośrednie konsekwencje - rozumiane jako wysokość finansowego uszczerbku dla dochodów - w poszczególnych latach (z wyjątkiem ostatnich czterech lat) były prawie identyczne. Drugi podatek od majątku nieruchomego - podatek rolny - ma znaczenie wyłącznie dla obszarów wiejskich. Uszczerbek dla dochodów własnych w związku z wprowadzonymi obniżkami tego podatku był jednak bardzo zmienny. Wydaje się, że duże wahania stawek podatkowych, wynikające ze zmian ceny żyta, decydowały o dostosowawczym charakterze polityki podatkowej gmin wiejskich. Powiązanie podatku z ceną tego marginalnego dla większości gospodarstw rolnych produktu rolnego spowodowało, że ustalano wysokość podatku (w zależności od warunków 
atmosferycznych czy sytuacji na rynkach rolnych) na bardzo wysokim bądź niskim poziomie. W przypadku trzeciego analizowanego podatku - podatku od środków transportowych - w całym badanym okresie władze lokalne aktywnie korzystały z przysługujących im prerogatyw władztwa podatkowego.

W 2019 r. w zakresie podatku od nieruchomości największe obniżki stawek były stosowane przez gminy wiejskie - 16,92\% dochodów wykonanych. Nieco mniejsze obniżki wprowadzano w gminach miejsko-wiejskich - 14,69\% i w gminach miejskich - 10,02\%. W znikomym stopniu stosowano je w miastach na prawach powiatu (średnio 3,15\% wykonanych dochodów w 2019 r.). Analogiczna sytuacja wystąpiła w przypadku podatku rolnego - najchętniej stosowano obniżki w gminach wiejskich (9,57\%), a następnie w gminach miejsko-wiejskich $(6,94 \%)$ i gminach miejskich $(5,82 \%)$. Miasta na prawach powiatu z powodu obniżek stawek podatkowych w podatku rolnym zmniejszyły swoje dochody jedynie o 3,52\%. Jeśli chodzi o podatek od środków transportowych, to największe obniżki w 2019 r. były stosowane przez gminy miejskie (89,99\%), nieco niższe przez gminy wiejskie $(88,23 \%)$ oraz gminy miejsko-wiejskie $(86,86 \%)$. Mimo że obniżka stawek w miastach na prawach powiatu w ujęciu kwotowym była podobna do tej stosowanej przez gminy miejsko-wiejskie, to stanowiła $72,36 \%$ wykonanych dochodów z tego podatku.

Dla całego badanego okresu średnia strata w wyniku stosowanych obniżek stawek w podatku od nieruchomości wyniosła 11,67\% dochodów z tego podatku, z czego w przypadku miast na prawach powiatu było to 4,14\%, gmin miejskich - 11,77\%, gmin miejsko-wiejskich - 17,34\%, a gmin wiejskich - 19,6\%. W zakresie podatku rolnego było to zaś $20,31 \%$, w tym w przypadku miast na prawach powiatu - 3,94\%, gmin miejskich - 9,08\%, gmin miejsko-wiejskich - 17,80\%, a gmin wiejskich - 22,44\%. W podatku od środków transportowych średnia wyniosła $62,84 \%$, z czego w przypadku miast na prawach powiatu - 52,91\%, gmin miejskich - 65,33\%, gmin miejsko-wiejskich - 66,12\%, a gmin wiejskich - 70,86\%.

Podsumowując: dzięki podjętym w artykule badaniom teoretyczno-empirycznym możliwe było zweryfikowanie hipotez przyjętych we wstępie opracowania, co znajduje potwierdzenie m.in. w zestawionych i zinterpretowanych danych empirycznych.

\section{Bibliografia}

Brzozowska K., Kogut-Jaworska M., Władztwo podatkowe w ocenie samodzielności dochodowej gmin w Polsce, „Annales Universitatis Mariae Curie-Skłodowska. Sectio H. Oeconomia” 2016, t. 50, nr 1, https://doi. org/10.17951/h.2016.50.1.327.

Dolewka Z., Tax Control of the Commune and its Consequences, „Prace Naukowe Uniwersytetu Ekonomicznego we Wrocławiu" 2017, nr 476, https://doi.org/10.15611/pn.2017.476.12.

Dziemianowicz R., Budlewska R., Czy tax expenditures stosowane w podatkach państwowych mają wpływ na dochody JST? Przyczynek do dyskusji, „Prace Naukowe Uniwersytetu Ekonomicznego we Wrocławiu” 2015, nr 404 [Finanse samorzqdu terytorialnego, red. L. Patrzałek, W. Kociemska].

Dziuba J., Polityka podatkowa gmin wiejskich w Polsce w latach 2006-2017, „Zeszyty Naukowe Szkoły Głównej Gospodarstwa Wiejskiego. Ekonomika i Organizacja Gospodarki Żywnościowej" 2019, nr 125, http://dx.doi. org/10.22630/EIOGZ.2019.125.3. 
Dziuba J., Zróżnicowanie fiskalnych skutków polityki podatkowej jednostek samorzq̨du terytorialnego, „Annales Universitatis Mariae Curie-Skłodowska. Sectio H. Oeconomia" 2016, t. 50, nr1, http://dx.doi.org/10.17951/h.2016.50.1.351.

Felis P., Podatki od nieruchomości a polityka podatkowa gmin w Polsce, Oficyna Wydawnicza SGH, Warszawa 2015.

Felis P., Malinowska-Misiąg E., Otczyk G., Rosłaniec H., Planowanie dochodów z podatków lokalnych w Polsce, Oficyna Wydawnicza SGH, Warszawa 2020.

Felis P., Rosłaniec H., Wykorzystanie podatku od nieruchomości w lokalnej polityce podatkowej miast Unii Metropolii Polskich, „Gospodarka Narodowa” 2017, t. 288, nr 2, https://doi.org/10.33119/GN/100735.

Felis P., Rosłaniec H., Zróżnicowanie fiskalnych skutków polityki podatkowej gmin w Polsce w zakresie podatku od środków transportowych, „Studia Regionalne i Lokalne” 2017, nr 2(68), http://dx.doi.org/10.7366/150949956805.

Filipiak B.Z., Polityka podatkowa gmin czy realizacja władztwa podatkowego?, „Finanse, Rynki Finansowe, Ubezpieczenia" 2015, nr 76, t. 1, http://dx.doi.org/10.18276/frfu.2015.76/1-19.

Kobiałka A., Polityka podatkowa gmin w kontekście samodzielności finansowej, „Prace Naukowe Uniwersytetu Ekonomicznego we Wrocławiu" 2017, nr 488, http://dx.doi.org/10.15611/pn.2017.488.06.

Korolewska M., Polityka podatkowa gmin i miast na prawach powiatu w zakresie podatku od nieruchomości a wspieranie przedsiębiorczości przez samorząd terytorialny, „Studia BAS” 2014, nr 1(37) [Rozwój przedsiębiorczości oraz sektora małych i średnich przedsiębiorstw, red. G. Gołębiowski].

Kulicki J., Władztwo podatkowe państwa i samorzqdu terytorialnego w zakresie podatków dochodowych - model scentralizowany czy zdecentralizowany?, „Studia BAS” 2018, nr 2(54) [Wybrane zagadnienia reformy opodatkowania dochodów osób fizycznych i prawnych w Polsce, red. J. Kulicki], https://doi.org/10.31268/StudiaBAS.2018.05

Łukomska J., Swianiewicz P., Polityka podatkowa władz lokalnych w Polsce, Municipium, Warszawa 2015, https:// doi.org/10.13140/RG.2.1.1928.0089.

Ministerstwo Finansów, Sprawozdanie Rb-27S, Bazy danych po IV kwartałach, www.gov.pl/web/finanse/bazy-danych.

Olejniczak J., Bednarska-Olejniczak D., Mači J., Svobodová L., Real Property Tax in Polish Communes of the Polish-Czech Border Region, „Hradec Economic Days”, International Scientific Conference, Hradec, 2-3 April 2020, https://doi.org/10.36689/uhk/hed/2020-01-032.

Poniatowicz M., Wyszkowska D., Stymulowanie rozwoju lokalnej przedsiębiorczości a konkurencja podatkowa gmin, „Zeszyty Naukowe Wyższej Szkoły Bankowej w Poznaniu” 2014, nr 1(52).

Przygodzka R., Władztwo podatkowe a stabilność finansowa gmin , "Nierówności Społeczne a Wzrost Gospodarczy” 2014, nr 4(40), http://polona.pl/item/43529479.

Skica T., Kiebała A., Wołowiec T., Stymulowanie lokalnej konkurencyjności gmin na przykładzie podatku od środków transportowych, "Studia Regionalne i Lokalne” 2011, nr 2(44).

Swianiewicz P., Łukomska J., Lokalna konkurencja podatkowa w Polsce, „Studia Regionalne i Lokalne”, t. 64, nr 2, https://doi.org/10.7366/1509499526401.

Śmiechowicz J., Stabilność dochodów gmin w kontekście ich władztwa podatkowego i fakultatywności opłat lokalnych, „Studia Ekonomiczne. Zeszyty Naukowe Uniwersytetu Ekonomicznego w Katowicach” 2016, nr 294.

Śmiechowicz J., Znaczenie podatków lokalnych w kontekście stabilizacji fiskalnejJST na przykładzie gmin województwa lubelskiego [w:] Dochody podatkowe samorządu terytorialnego i czynniki je kształtujące, red. J. Szołno-Koguc, J. Śmiechowicz, Wydawnictwo UMCS, Lublin 2019. 
Wyszkowski A., Koncepcja tax expenditures w systemie podatkowym, "Gospodarka Narodowa” 2010, t. 242, nr 9, https://doi.org/10.33119/GN/101165.

\section{Akty prawne}

Ustawa z dnia 28 lipca 1983 r. o podatku od spadków i darowizn (Dz.U. 2019, poz. 1813, ze zm.).

Ustawa z dnia 15 listopada 1984 r. o podatku rolnym (Dz.U. 2020, poz. 333).

Ustawa z dnia 12 stycznia 1992 r. o podatkach i opłatach lokalnych (Dz.U. 2019, poz. 1170, ze zm.).

Ustawa z dnia 20 listopada 1998 r. o zryczałtowanym podatku dochodowym od niektórych przychodów osiąganych przez osoby fizyczne (Dz.U. 2019, poz. 43, ze zm.).

Ustawa z dnia 9 września 2000 r. o podatku od czynności cywilnoprawnych (Dz.U. 2020, poz. 815, ze zm.). Ustawa z dnia 30 października 2002 r. o podatku leśnym (Dz.U. 2019, poz. 888).

Ustawa z dnia 13 listopada 2003 r. o dochodach jednostek samorządu terytorialnego (Dz.U. 2021, poz. 38, ze zm.). 


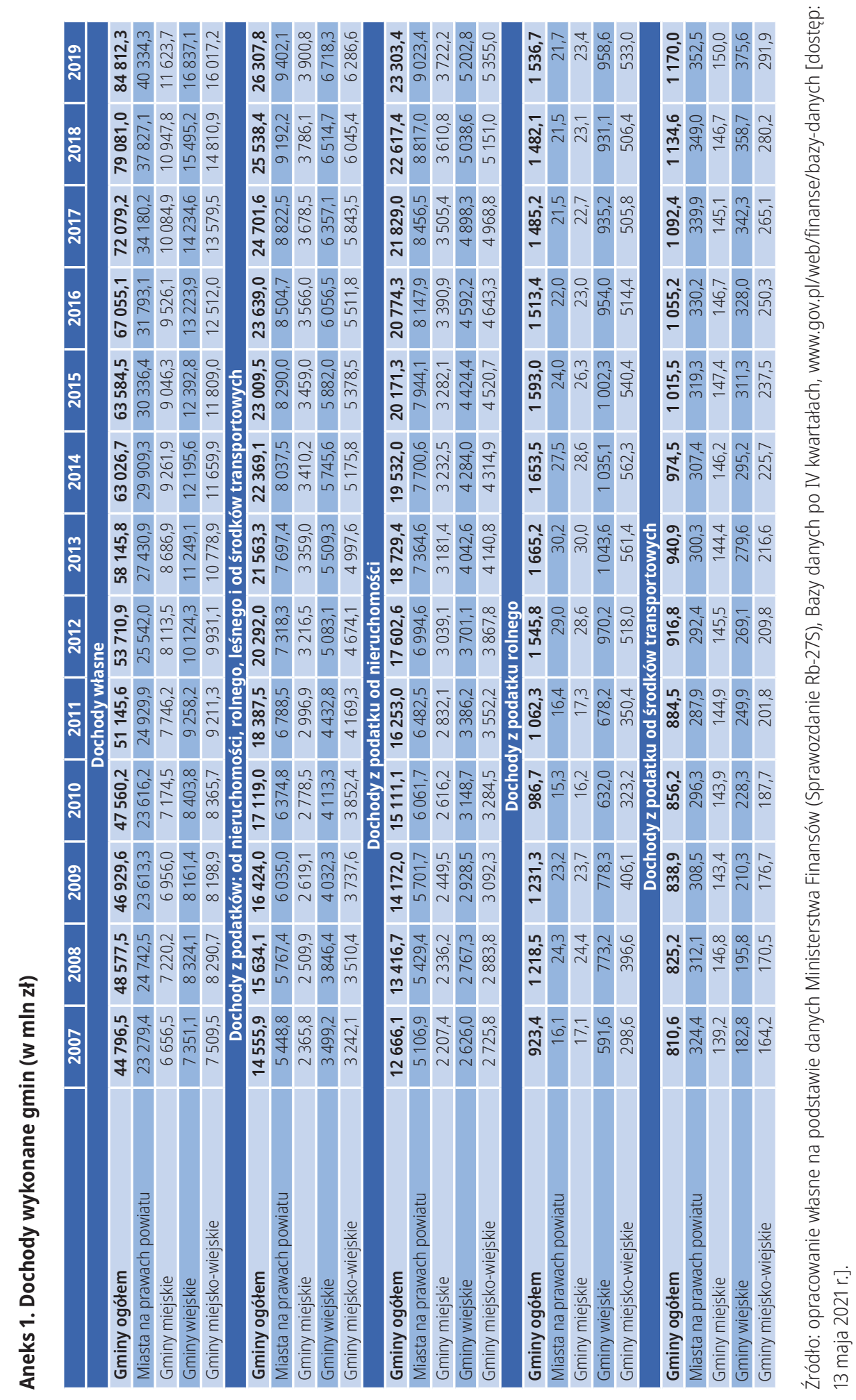



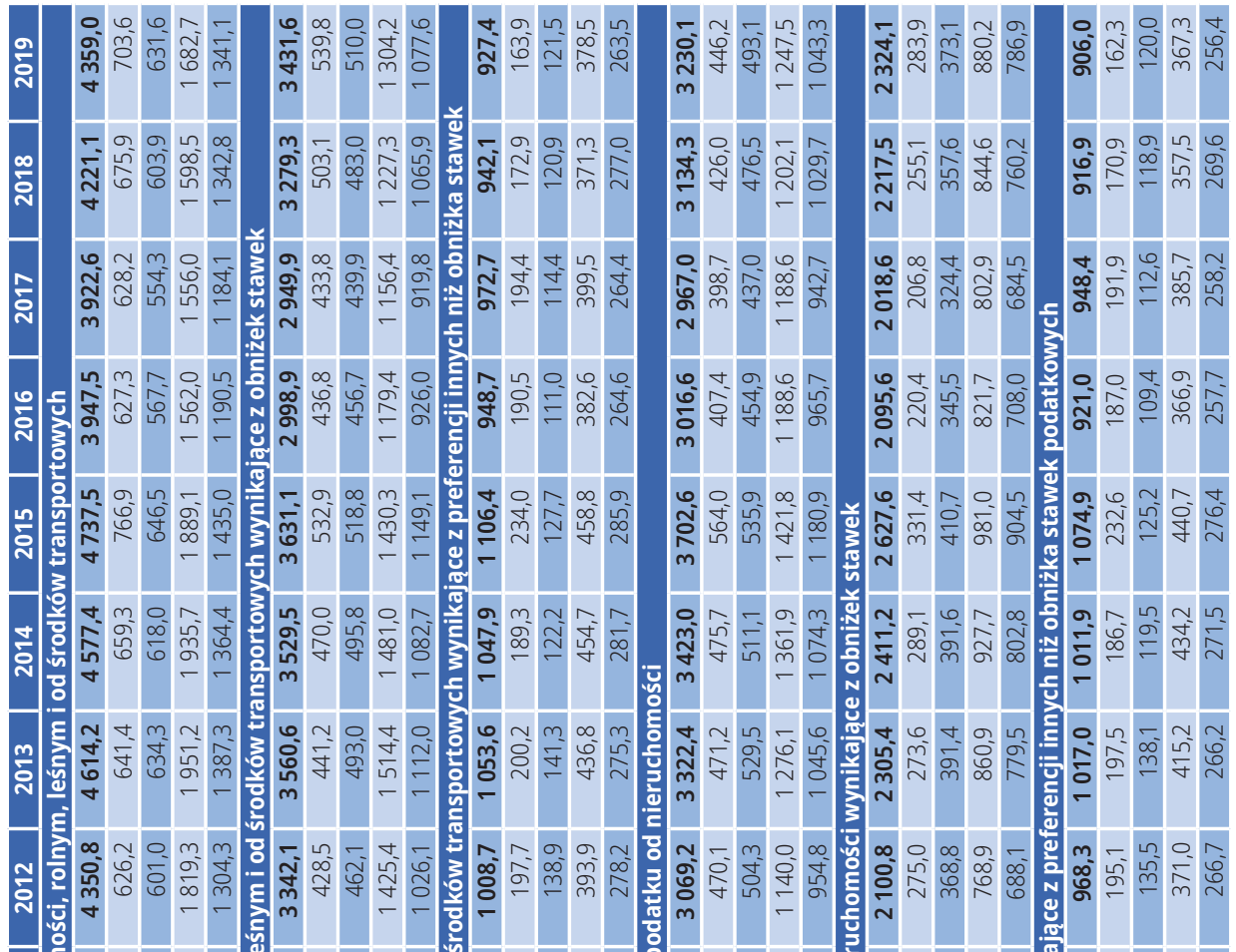

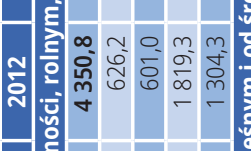

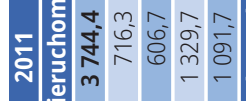

- a $0 \mathrm{mo}$
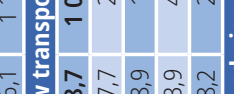

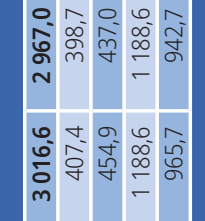




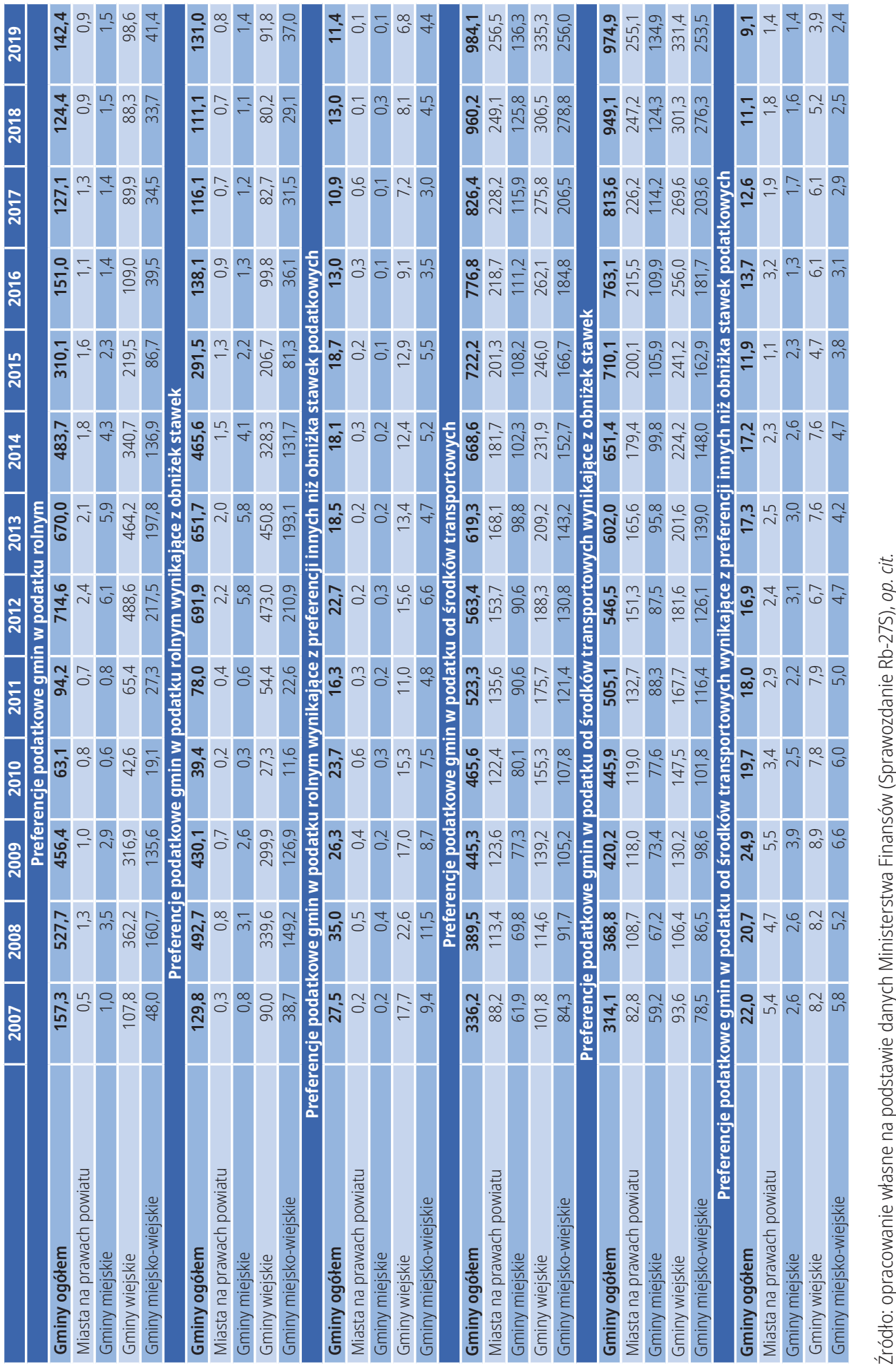

